\title{
HÜKMÜN AÇIKLANMASININ GERİ BIRAKILMASI: YASAL ŞARTLARIN YERİNDELİĞİ VE KARARIN HUKUKİ ETKILLERI ÜZERINE BİR DEĞERLENDİRME
}

\author{
M. Emre TULAY*
}

\section{$\ddot{O} Z$}

Ceza muhakemesinde erteleme kurumunun yansimalartndan olan hükmün açıklanmasının geri bırakılması, uygulamada sıklikla başvurulan kurumlar arasındadır. Sanığın hukuki menfaati gözetilerek ihdas edilen hükmün açıklanmasının geri bırakılması kurumunun, yasal şartları yönüyle bu amaçla ne ölçüde bağdaş̧tığl, yargllamanin yürüyüşü ve ceza muhakemesine hakim ilkeler ışı̆̆ııda irdelenmelidir. Bu gayeyi takiben eserde, kurumun hukuki niteliği tartışılmış, yasal koşul ve istisnalar değerlendirilmiş, sanık hakkında doğurduğu sonuçlar incelenmişstir. Ayrıca, hükmün açıklanmasının geri bırakılması kararına karşı öngörülen itiraz kanun yolunun kapsamı, itiraz merciin bağll olduğu sinırlar ve kanun yolu tercihinin yerindeliğ $i$ ele alınmıştır. Konuyla ilgili içtihat ve doktrinde yer alan görüşler değerlendirilmiş, tespit edilen hukuki sorunlara ilişskin çözüm önerileri paylaşılmıştır.

Anahtar Kelimeler: Hükmün Açıllanmasının Geri Bırakılması, Erteleme, Sanı̆̆ın Kabulü, İkrar, İtiraz

\section{DEFERRAL OF THE ANNOUNCEMENT OF VERDICT: AN ASSESSMENT ON THE APPROPRIATENESS OF LEGAL CONDITIONS AND THE LEGAL EFFECTS OF THE DECISION}

\section{ABSTRACT}

The institution of deferral of the announcement of verdict, which is one of the reflections of the deferment institution in criminal procedure, is among the institutions that are frequently applied in the Turkish Criminal Law practice. It should be examined to what extent the institution of deferral of the announcement of verdict, which was created with the claim that it is in favor of the defendant, is compatible with this purpose in terms of legal conditions of institution. Therefore, in our study, the legal nature of the institution was discussed, the legal conditions and exceptions defined in

* Dr. Öğr. Üyesi, Süleyman Demirel Üniversitesi Hukuk Fakültesi Ceza ve Ceza Muhakemesi Hukuku Ana Bilim Dalı/ISPARTA e-posta: muhammedtulay@sdu.edu.tr,

ORCID: 0000-0002-7828-8302.

DOI : : 10.34246/ahbvuhfd. 1018786

Yayın Kuruluna Ulaştığı Tarih $\quad$ : 04/05/2021

Yayınlanmasının Uygun Görüldüğü Tarih: 07/09/2021 
Article 231 of the Criminal Procedure Code were evaluated, and the consequences of the decision on the defendant were examined. In addition, the scope of the objection legal remedy foreseen against the decision of deferral of the announcement of verdict, the limits which the objection authority is bound in the analysis of the decision, and the appropriateness of the choice of legal remedy have been discussed. The opinions contained in the supreme court decisions and doctrine on the subject have been evaluated. Solutions for the identified legal problems have been shared.

Keywords: Deferral of the Announcement of Verdict, Deferral, Conviction, Consent of the Defendant, Objection

\section{GENEL OLARAK}

Türk Ceza Muhakemesi uygulamasında sıklıkla başvurulan hükmün açıklanmasının geri bırakılması (HAGB) kurumu ${ }^{1}$, öncelikle 15.07.2005 tarih ve 5395 sayılı Çocuk Koruma Kanunu m. 23’te düzenlenmiş, 6.12.2006 tarih ve 5560 sayılı Kanun ile CMK sistemine dahil edilmiştir.

Sanık ile devlet arasındaki yargılama ve ceza ilişkisini geçici olarak sona erdiren HAGB kurumu² ile cezai yönden hafif suçlarda ${ }^{3}$ toplum barışına katkıda bulunmak ${ }^{4}$, mahkemelerin iş yükünü kısmen azaltmak ${ }^{5}$, cezaevi

Adli Sicil ve İstatistik Genel Müdürlüğü tarafından açıklanan son verilere göre, 2019 yılında karara bağlanan 4.447.362 adet dosyanın 562.854 tanesi HAGB ile neticelenmiştir. $\mathrm{Bu}$ say1, toplam dosya adedinin \%12,7'sine tekabül etmektedir. Ancak 2012-2019 aras1 dönem baz alındığında, HAGB açısından 2014 yılından itibaren oransal bir düşüş olduğu gözlemlenmektedir. Nitekim toplam dosya sayısında çok yakın olunan 2013 yılında bu oran \%17,7'dir (bkz. Adli Sicil ve İstatistik Genel Müdürlüğü, Adli İstatistikler 2019, <https:// adlisicil.adalet.gov.tr/Resimler/SayfaDokuman/1062020170359HizmeteOzel-2019bask\%C4\%B1-\%C4\%B0SA.pdf> Erişim Tarihi 31 Ağustos 2021). Söz konusu düşüşün temelinde alternatif çözüm yollarının, bu anlamda yıl aralığı dikkate alındığında uzlaştırma kurumunun daha uygulanabilir hale gelmesinin etkili olduğu söylenebilir.

2 Hamide Zafer, Ceza Hukuku Genel Hükümler, 7. Bas1, Beta Yayınevi, 2019, s. 715.

3 Madde gerekçesi (5560 sayılı Kanun m. 23).

4 Madde gerekçesi (5560 sayılı Kanun m. 23): "Cezaya mahkumiyete bağlı yoksunlukların doğmaması için, kişi açısından, denetim süresi zarfinda yeni bir suç işlememesi ve özellikle mağdurun mağduriyetini gidermek amacına yönelik olarak kendisine yüklenen belirli yükümlülüklere uygun davranması koşuluyla, hakkında cezaya hükmedilmemesi, toplum barışının sağlanması bakımından, cezaya mahkumiyete nazaran daha etkili olabilecektir. Bu amaca hizmet eden hükmün açıklanmasının geri bırakılmasının, müessese olarak hukuk sistemimize kazandırllmasında bir gereklilik bulunmaktadır".

5 Yusuf Solmaz Balo, "Hükmün Açıklanmasının Ertelenmesi Kurumu Üzerinden Ulaşılmak 
yoğunluğunu düşürmek ve cezaevi kültürünün kişi üzerinde bıraktığı olumsuz etkiyi, denetim süresi öngörerek şartlı şekilde kaldırmak amaçlanmıştır. ${ }^{6}$ Diğer yandan, henüz cezanın infazına geçilmeden kişinin 1 slahı istenmekte ${ }^{7}$,

İstenen Hedeflerin Türkiye Bakımından Gerçekleştirilebilirliği”, 2016, 11(30), CHD, s. 197. HAGB kurumunun ihdasının ana nedeni, -özellikle kanun yolu dikkate alındığındaYargıtay'ın iş yükünün azaltılmasıdır, Hakan Karakehya, Ceza Muhakemesi Hukuku, 2. Bas1, Savaş Yayınevi, 2016, s. 561. Esasen HAGB kurumu ile ceza mahkemelerinin iş yükünü azaltmak pratikte mümkün değildir. Çünkü HAGB kararı verilebilmesi için evvela işlendiği iddia olunan suçun sabit görülmesi, bunun için de bir ceza yargılamasının tüm koşullarıyla tamamlanması gerekir. Mahkemelerin iş yükünün azaltılması amacı, daha çok "duruşma açılmasının ertelenmesi” kurumu ile sağlanabilir, Veli Özer Özbek/İsa Başbüyük, "Hükmün Açıklanmasının Geriye Bırakılması Kararlarına İtirazın İncelenme Usulünün Mağdur/Suçtan Zarar Gören Bakımından Ortaya Çıkardı̆̆g Sorun Üzerine”, 2013, 8(21), CHD, s. 18. HAGB ile mahkemelerin iș yükünün $\operatorname{arttığ~} 1$, esasen kurumla güdülen amacın kanunda yer alan erteleme kurumlarıyla pekala sağlanabileceği yönünde Hakan A. Yavuz, Ceza Muhakemesinde Kovuşturmaya Alternatif Yöntemler, Adalet Yayınevi, 2019, s. 243.

6 Balo, s. 169; Can Yalçın, Hükmün Açıklanmasının Geri Bırakılması, Seçkin Yayınevi, 2021, s. 85; Cumhur Şahin/Neslihan Göktürk, Ceza Muhakemesi Hukuku -II-, 7. Bası, Seçkin Yayınevi, 2018, s. 194; Doğan Soyaslan, Ceza Muhakemesi Hukuku, 7. Bask1, Yetkin Yayınevi, 2018, s. 445; Enver Kumbasar, Hükmün Açıklanmasının Geri Bırakılması, Seçkin Yayınevi, 2012, s. 25; Fahri Gökcen Taner, "Hükmün Açıklanmasının Ertelenmesinin (Geri Bırakılmasının) Hukuki Niteliği ve Ertelemeyi Kabul Edip Etmediğinin Sanığa Duruşma Devresinin Sona Ermesinden Önce Sorulmasının Hukuka Aykırılığı Üzerine", 2011, 4, AnkBD, s. 292; Murat Volkan Dülger, Ceza Hukuku Genel Hükümler, 1. Bask1, Hukuk Akademisi Yayınevi, 2021, s. 936; Mustafa Artuç, "Hükmün Açıklanmasının Geri Bırakılması", 2008, 3(21), THD, s. 108; Mustafa Artuç/Tahir Hırslı, Hüküm Kurma Esasları, 4. Bask1, Adalet Yayınevi, 2011, s. 317; Turan Temur, "Hükmün Açıklanmasının Geri Bırakılması", 2014, 88(5), THD, s. 143. Doktrinde Yurtcan, HAGB için dile getirilen hukuki gerekçeyi genel olarak paylașmakla birlikte, karșılaștırmalı hukukta da kabul gören hapis cezasının ertelenmesi kurumunun yanı sıra HAGB'nin düzenlenmiş olmasını, hem ceza hukuku sistemi, hem de kurumun amacı bakımından isabetsiz bulmaktadır, Erdener Yurtcan, Ceza Yargılaması Hukuku, 16. Bası, Seçkin Yayınevi, 2019, s. 563. Belirtilen yönleriyle HAGB, şarta bağlı af yöntemi olarak da anılmaktadır, bkz. Ersan Şen/Mert Maviş, Hükmün Açıklanmasının Geri Bırakılması (HAGB), Seçkin Yayınevi, 2014, s. 14. CMK m. 231/5 ile benzerlik gösteren ve ceza saklı tutularak adli tevbih ve koșullarını düzenleyen Alman Ceza Kanunu m. 59 ( $\$ 59$ StGB) hükmüyle güdülen amacın, fiili ceza yaptırımı uygulanmadan failin ıslahının sağlanması olduğu belirtilmektedir, Strafgesetzbuch Kommentar Schönke/ Schröder, 30. Bask1, C.H.Beck Yayınevi, 2019 (S/S-Kinzig), §59 StGB Rn. 2.

7 “... Mukayeseli hukukta suç ve suçlulukla mücadele, suç işlenmesinin önlenmesi ve caydırıcılık açısından bu ve buna benzer kurumlara geniş biçimde yer verildiği görülmektedir", AYM, E. 2009/222, K. 2009/55, 07.05.2009 (RG: 07.10.2009, S: 27369). Ayrıca bkz. Anıl Akyıldız, "Hükmün Açıklanmasının Geri Bırakılması Kurumuna İlişkin Sorunlar", 2020, 17(3), YÜHFD, s. 69; Eser Dursun, "Hükmün Açıklanmasının Geri Bırakılmasına ilișkin Teorik Bir İnceleme”, 2014, 9(26), CHD, s. 146; Kubilay Tașdemir, Hükmün Açıklanmasının Geri Bırakılması, (Yazarın kendi yayını), 2016, s. 4; Mahmut Koca/İlhan Üzülmez, Türk Ceza Hukuku Genel Hükümler, 13. Baskı, Seçkin Yayınevi, 2020, s. 596; Nevzat Toroslu/Metin Feyzioğlu, Ceza Muhakemesi Hukuku, 20. Baskı, Savaş Yayınevi, 2020, s. 364. 
adeta sanığa ikinci bir şans tanınmaktadır. ${ }^{8}$ Kamu davasının mecburiliği ilkesi, HAGB kurumunun öngörülmesiyle kovuşturma evresi için de yumuşatılmıştır. ${ }^{9}$ Bütüncül bakıldığında, yasal şartları açıkça belirlenmiş olan HAGB ve benzeri kurumların varlığı, hümanist bir cezalandırma siyasetinin tezahürü olarak görülmektedir. ${ }^{10}$

Mahkeme hükmünün sanık hakkında sonuç doğurmaması olarak karşımıza çıkan HAGB kurumunun düzenleniş gerekçeleri arasında sanığın lekelenmeme hakk1 da gösterilmektedir. ${ }^{11}$ Ancak HAGB kararında hükmün açıklanması ertelense de, sanık hakkında adli para cezası ya da iki yıla kadar hapis cezasına karar verilmiş, işlediği suç sabit görülmüştür. ${ }^{12} \mathrm{Bu}$ yönüyle HAGB kurumunun ihdasına gerekçe olarak lekelenmeme hakkının gösterilmesinin çok yerinde olmadığı belirtilmelidir. ${ }^{13}$

HAGB kurumunun uygulama sınırları iyi bir şekilde tespit edilmezse, lehe görünen bu kurumun adeta bir suç patlamasına yol açması da muhtemeldir. Bu sebeple kanun koyucu, HAGB kararını objektif ve sübjektif şartların varlığına bağlamıştır. ${ }^{14}$ Sanık lehine bir kurum ihdas edilirken sanığın başka suçlara eğiliminin önlenmek istenmesi, yasal şartların tahlilinde tercih edilen yorum açısından da belirleyici olacaktır.

Aşağıda ayrıntılı inceleneceği üzere, erteleme kurumunu genişleten nitelikte olan HAGB'de (CMK m. 231/5-son) ${ }^{15}$, aslında hükmün açıklanmas1

8 Ahmet Gökcen/Murat Balcı/M.Emin Alşahin/Kerim Çakır, Ceza Muhakemesi Hukuku, 4. Bask1, Adalet Yayınevi, 2020, s. 630; Devrim Güngör/Güneş Okuyucu-Ergün, "Hükmün Açıklanmasının Geri Bırakılması", 2016, 65(4), AÜHFD, s. 1954; Emir Kaya, "İnsan Hakları Açısından Hükmün Açıklanmasının Geri Bırakılması”, 2013, 3, AnkBD, s. 415; Taner, AnkBD, s. 292.

9 Y. CGK, E. 2009/9-7, K. 2009/24, 17.02.2009. Ayrıca bkz. Ali İhsan İpek, Hükmün Açıklanmasının Geri Bırakılması, Adalet Yayınevi, 2010, s. 18.

10 Özbek/Başbüyük, s. 16.

11 Y. CGK, E. 2011/2-376, K. 2012/90, 13.03.2012. Ayrıca bkz. Adem Kartal, "Hapis Cezasının Ertelenmesi ile Hükmün Açıklanmasının Geri Bırakılmasının Sonuçları Bakımından Karşılaştırılması”, 2016, 11(114), THD, s. 69; Ali Parlar, Hükmün Açıklanmasının Geri Bırakılması ve Erteleme, 2. Bası, Bilge Yayınevi, 2015, s. 14; Taşdemir, s. 4.

12 Bahri Öztürk (Editör), Nazari ve Uygulamalı Ceza Muhakemesi Hukuku, 13. Baskı, Seçkin Yayınevi, 2019, s. 644; İzzet Özgenç, Türk Ceza Hukuku Genel Hükümler, 14. Bas1, Seçkin Yayınevi, 2018, s 714; Artuç/Hırslı, s. 321; Balo, s. 171.

13 Veli Özer Özbek/Koray Doğan/Pınar Bacaksız, Ceza Muhakemesi Hukuku, 12. Bask1, Seçkin Yayınevi, 2019, s. 705.

14 Sevinç Olgun, "Ceza Muhakemesi Kanununa Göre Hükmün Açıklanmasının Geri Brakılması", 2008, 3(22), THD, s. 69.

15 CMK m. 231/5-son: "Hükmün açıklanmasının geri bırakılması, kurulan hükmün sanık 
değil, hukuki sonuç doğurması ertelenmektedir. ${ }^{16}$ Çalışmamızda, HAGB'nin hukuki etkileri ile kurumun kanuni tanımı ve ihdas gayesinin ne derece örtüştüğü titizlikle irdelenecektir.

\section{HÜKMÜN AÇIKLANMASININ GERI BIRAKILMASI KARARININ YASAL ŞARTLARI}

Kanun koyucu, HAGB kararı için objektif ve sübjektif nitelikte şartlar öngörmüş ve kurumun CMK m. 231 kapsamında tatbikini hakimin takdirine bırakmıştır. ${ }^{17}$ Ancak kurum için aranan objektif şartlar oluşmasına rağmen hükmün açıklanması durumunda, HAGB kararının niçin uygulanmadığının gerekçesi, kararda açıkça yer almalıdır. ${ }^{18}$ Ayrıca, HAGB'nin hükmün hukuki sonuç doğurmaması yönüyle daha lehe olduğu dikkate alındığında, öncelikle bu kurumun gözetilmesi, kararın bu yönde olmaması halinde ise diğer lehe kurumların (TCK m.50, 51) tercih edilebileceği önemle belirtilmelidir. ${ }^{19}$

hakkında bir hukukî sonuç doğurmamasını ifade eder". Madde gerekçesi (5560 sayılı Kanun m. 23): “...bu hüküm (HAGB) sanık hakkında hukuki sonuç doğurmamaktadır. Başka bir ifadeyle, kurulan hükmün hukuki sonuç doğurup doğurmaması, belli bir süreye ve bazı şartlara bağlı kilınmaktadır".

16 Kurumun adının "mahkumiyet hükmünün açıklanmasının ertelenmesi" şeklinde düzenlenmesi gerektiği görüşünde Uğur Güner, "Türk Ceza Hukukunda Mahkumiyet Hükmünün Açıklanmasının Ertelenmesi", 2014, 9(25), CHD, s. 182. "Hükmün sonuç doğurmasının şartlı olarak ertelenmesi” kavramının daha isabetli olacağı yönünde Seyithan Güneş, Hükmün Açıklanmasının Geri Bırakılması, On İki Levha Yayınevi, 2018, s. 3.

17 CMK m. 231/5'te öngörülen HAGB esas olarak mahkemenin takdirine birakılmakla birlikte, kanunda farklı düzenlemeler öngörülebilir. Nitekim TCK m. 191 kapsamındaki koşulların varlığı halinde HAGB kararı verilmesi zorunludur. §59 StGB hükmünde kullanılan "kann... verwarnen" ifadesi de, yasal şartlar dahilinde kurumun tatbikinin mahkemenin takdirine bırakıldığını göstermektedir, Münchener Kommentar zum StGB, 4. Baskı, C.H.Beck Yayınevi, 2020 (MüKoStGB/Groß/Kulhanek), § 59 Rn. 10.

18 "Şartları oluştuğu halde hükmün açılklanması ile ilgili hiçbir değerlendirme yapılmaması hakimin takdir hakkına taalluk eden bir husus değildir", Y. CGK, E. 2014/4-128, K. 2015/388, 10.11.2015. Ayrica bkz. Nur Centel/Hamide Zafer, Ceza Muhakemesi Hukuku, 19. Bas1, Beta Yayınevi, 2020, s. 873; Öztürk, s. 649; Şahin/Göktürk, s. 199.

19 Artuç/Hırsl1, s. 317; Centel/Zafer, s. 874; Demirbaş, s. 701; Dülger, s. 936; Kartal, s. 68; Kumbasar, s. 47; Özgenç, s. 723; Öztürk, s. 644; Şahin/Göktürk, s. 200; Yurtcan, s. 784. Bu konuda, 3359 Sayılı Kanun Ek Madde 12'de yapılan değişiklik örnek bir inceleme olarak ele alınmalıdır. Söz konusu değişiklikle, sağlık personeli ile yardımcı sağlık personeline karşı işlenen yaralama, tehdit, hakaret ve görevi yaptırmamak için direnme suçlarında TCK m. 51 uygulanamazken, şartları dahilinde HAGB uygulanabilecektir. Yasal kurumların uygulanmasına elbette özel düzenlemelerle istisna getirilebilir. Ne var ki kanun koyucunun, hapis cezasının ertelenmesini kapsam dışı bırakıp, daha lehe olan HAGB kurumunda herhangi bir istisna getirmemesi tutarsız olmuştur. 
Hükmün Açıklanmasının Geri Bırakılması: Yasal Şartların Yerindeliği ...

Nitekim Yargıtay, aksi bir tutumun hukuka aykırı olacağı görüşündedir. ${ }^{20}$

\section{A. Objektif Şartlar}

\section{Daha önceden kasıtlı bir suçtan mahkum olmamak}

HAGB için öngörülen ilk şart, sanığın daha önceden kasıtlı bir suçtan mahkum olmamasıdır (CMK m. 231/6-a). Burada yer alan "kast", doğrudan veya olası kast olabilir. ${ }^{21}$ Mahkumiyetin türü, süresi ve miktarına bağl1 olmaksızın, basit ya da bilinçli taksirle işlenen ve mahkum olunan suç ise, sonraki fiil için yapılan yargılamada HAGB'ye mani değildir. ${ }^{22}$ Daha önceki suçtan dolayı yapılan yargılamada sadece güvenlik tedbirine hükmedilmesi de, kurumun uygulanmasinı önlemez. ${ }^{23}$

CMK m. 231/6-a'da yer alan şartta kişinin daha önceki bir suçtan mahkumiyeti arandığ 1 için, söz konusu hükmün kesinleşmesi, hükmün infazına geçilmesi ya da infazın tamamlanması şart değildir. ${ }^{24}$

Önceki kasıtlı suçtan dolayı HAGB kararı verilmişse, bu karara ilişkin denetim süresi içinde işlenen yeni kasıtlı suçta HAGB uygulanamayacaktır (CMK m. 231/8). Ancak önceki HAGB için geçerli olan denetim süresi geçmiş ve düşme kararı verilmişse, artık mahkumiyet hükmü açıklanmadığından, sonraki suçta HAGB mümkündür.

Önceki kasıtlı suçtan mahkum olunan cezanın hapis ya da adli para cezası olması veya cezanın seçenek yaptırımlara çevrilmesinin etkisi aynıdır. $\mathrm{Bu}$ noktada, kamu davasının açılmasının ertelenmesinde CMK m. 171/3-a'da yer alan "Şüphelinin daha önce kasitlı bir suçtan dolayı hapis cezası ile mahkum olmamış bulunması" şartı ile kıyaslandığında, hem adli para cezasının, hem de sonuç cezanın TCK m. 50 kapsamında seçenek yaptırımlara çevrilmesinin, C.Savcısının kamu davası açmada takdir yetkisini engellemediği görülmektedir. Henüz soruşturma evresinde C.Savcısına tanınan bu imkanın, kovuşturma evresinde HAGB yönünden mahkemeye tanınmaması kanaatimizce tutarsız olmuştur.

20 Y. CGK, E. 2014/3-86, K. 2015/200, 09.06.2015.

21 Aras, s. 74; Şahin/Göktürk, s. 196; Şen/Maviş, s. 17.

22 Bahattin Aras, "Hükmün Açıklanmasının Geri Bırakılması Kurumu ve Uygulamadaki Sorunlar", 2008, 3(22), THD, s. 74; Karakehya, s. 566; Feridun Yenisey/Ayşe Nuhoğlu, Ceza Muhakemesi Hukuku, 8. Bask1, Seçkin Yayınevi, 2020, s. 799; Özgenç, s. 715.

23 Özgenç, s. 714; Şahin/Göktürk, s. 197.

24 Yenisey/Nuhoğlu, s. 799. 
Daha önce işlenmiş olan suç hakkında verilen hapis cezasının TCK m. 51 uyarınca ertelenmiş olması, sadece hükmün infazı açısından etki doğurduğundan, mahkumiyet hükmü varlığını ve haliyle HAGB engeli vasfını korur. ${ }^{25}$ Hapis cezası ertelenen kişi, kendisi için geçerli olan denetim süresini iyi halli geçirse dahi, kararın HAGB'ye etkisi değişmez. ${ }^{26}$ Keza önceki hüküm, TCK m. 58/2'deki süreler uyarınca artık tekerrüre esas olmasa bile HAGB engeli olmaya devam eder ${ }^{27}$; çünkü CMK m. 231/6' daki koşulda, önceki suça dair bir zaman sınırlaması yoktur. ${ }^{28}$

Sanığın daha önce işlediği ve mahkum olduğu suçun işlenmesi anında çocuk olması, sonraki yargılamada HAGB açısından aranan şartlarda bir farklılık doğurmamaktadır. ${ }^{29}$ Oysa yasal örneklere bakıldığında, fiili işlediği sırada çocuk olan kişi hakkında tekerrür hükümleri kapsam dış1 bırakılmıştır (TCK m 58/5). Keza bu kişiler, hak yoksunluklarından (TCK m. 53/1) etkilenmemektedir (TCK m. 53/4). ${ }^{30}$ Failin 1slahı temeline dayanan

25 Dülger, s. 938; Şahin/Göktürk, s. 196. TCK m. 51/8'e göre, hapis cezasi ertelenen hükümlü, denetim süresini yükümlülüklere uygun veya iyi halli olarak geçirmesi halinde cezası infaz edilmiş sayılmakta, mahkumiyet hükmü varlığını devam ettirmektedir. Bu konuda bkz. Faruk Turhan, "Yeni Türk Ceza Kanunu'na Göre Cezaların Ertelenmesi ve Uygulamada Ortaya Çıkan Bazı Sorunlar", 2006, X(3-4), EÜHFD, s. 28.

26 Şahin/Göktürk, s. 196. Ancak erteleme kararı eski TCK ve İnfaz kanuna göre verilmiş ve erteleme süresi olaysız geçmişse, sonradan işlenen suç nedeniyle HAGB kararı verilmesine engel teşkil etmez. Çünkü eski sistemde erteleme süresinin olaysız geçmesi halinde mahkumiyet vaki olmamış sayılmaktaydı, bkz. Turhan, "Cezaların Ertelenmesi”, s. 28.

27 Aras, s. 74; Dülger, s. 937; Necati Meran, "Hükmün Açıklanmasının Geri Bırakılması Konusunda Bazı Çözüm Önerileri”, 2008, 3(23), THD, s. 66; Özgenç, s. 715; Şahin/ Göktürk, s. 196. Ne var ki Yargıtay Ceza Genel Kurulu, 2009 tarihli kararında "Eski yasa döneminde işlenip, adli sicilden silinme koşulları oluşmuş olan mahkumiyetler ile ertelenmiş ve vaki olmamış sayılmasına karar verilen mahkumiyetlerin, hükmün açıklanmasının geri bırakılmasına yasal engel oluşturmayacağl, yeni dönemde işlenen suçlar açısından ise, infazdan sonra 5237 sayll Yasa'nın 58. maddesinde belirtilen tekerrür sürelerinin esas alınmasının hakkaniyete uygun bir çözüm olacağı" yönünde karar vermiştir, Y. CGK, E. 2008/11-250, K. 2009/13, 03.02.2009. Yüksek Mahkeme içtihadı ile aynı yönde M.Emin Artuk/Ahmet Gökcen/M.Emin Alșahin/Kerim Çakır, Ceza Hukuku Genel Hükümler, 12. Bask1, Adalet Yayınevi, 2018, s. 841; Ali Tanju Sarıül, "Türk ve Alman Hukuku'nda Hükmün Açıklanmasının Geri Bırakılması”, 2015, 118, TBBD, s. 148; Hail Çığl1, "Yargıtay Kararları Çerçevesinde, Hükmün Açıklanmasının Geri Bırakılmasında Daha Önceden Kasıtlı Bir Suçtan Mahkum Olmama Şartına İlişkin Bir Değerlendirme”, 2014, 9(100), THD, s. 22; Karakehya, s. 566.

28 Önceki kasıtlı suç üzerinden belirlenen şartların, TCK m. 50 ve m. 51'de yer alan lehe düzenlemelere kıyasla daha sıkı olduğu ve bu durumun HAGB kurumunun işlerliğini sınırladığı görüşünde, Özgenç, s. 716; Şahin/Göktürk, s. 196.

29 Özgenç, s. 715; Yalçın, s. 166.

30 Taksirli suçlarda ise TCK m. 53/6 uyarınca hak yoksunluklarına karar verilebilir, bkz. 
HAGB kurumunda da, 18 yaşından küçüklerin işlediği suç -objektif koşul bakımından- HAGB engeli olmamalı ve bu konuda CMK m. 231/5 ya da ÇKK m. 23'te yasal düzenleme yapılmalıdır. ${ }^{31}$

Üzerinde durulan yasal şart açısından son olarak, "daha önce" ibaresi üzerinde durulmalıdır. HAGB engeli olan "daha önceki kasıtllı suç"ta esas alınacak zaman, HAGB'ye konu edilen suçun işlenme anı m1, yoksa bu suça ilişkin mahkumiyet hükmünün kesinleşmesi anı mıdır? Buradaki anlam karmaşasının sebebi, "daha önce işlenen suç" ibaresinin değil, "daha önce kasıtlı bir suçtan mahkum olmaması" ifadesinin tercih edilmesidir. Yargıtay bu şartı, kişi hakkında adli sicil kaydında yer alan ve infaz edilen ya da edilebilir mahkumiyet hükmünün varlığı şeklinde yorumlamaktadır. ${ }^{32} \mathrm{Bu}$ yorum neticesinde, önceki tarihli suç dosyası, sonradan işlenen suçun yargılaması sona erdiğinde hala derdest ise, sonraki tarihli suçta HAGB uygulanabilir. Aynı şekilde, önceki tarihli suç dosyası hakkında karar verileceği an, halihazırda sanık hakkında verilmiş HAGB kararı "mahkumiyet" niteliğinde olmadığından, dava HAGB ile sonlandırılabilir. Haliyle aynı sanık hakkında birden fazla HAGB kararı bulunabilir. ${ }^{33}$ Ancak bu tutum, CMK m. 231'de belirtilen sübjektif koşullar açısından tutarlı olmadığ 1 gibi $^{34}$, failin ıslahı amaciyla da uyumsuzdur. Ne var ki, kanun metninde kullanılan ifade bu tür bir yorumu mümkün kılmaktadır. O halde kanaatimizce, CMK m. 231/6a'da yer alan şart, "daha önceki tarihli ve kasten işlenmiş bir suçtan mahkum olmamak" şeklinde yeniden düzenlenmelidir. Önerilen bu yasal değişiklik sonrasinda mahkeme; bakmakta olduğu davada sona geldiğinde, dava konusu suçtan önceki tarihli olup devam eden bir yargılama söz konusuysa, ilgili davadaki neticeyi beklemelidir. Bu çerçevede, sonraki tarihte işlenen ve fakat mevcut yargılamadan daha önce mahkumiyetle sonuçlanan dosya ise, sanık açısından sübjektif kriter yönüyle olumsuz kanaat doğuracak ve HAGB engeli oluşturacaktır. Hukuki önerimiz karşısında yargılama sürecinin uzaması ihtimali doğsa da, kurumun amacıyla bağdaşan bir çözüm bulmak daha elzemdir. Çünkü böylece, dava konusu suçtan önce veya sonraki tarihte işlenmiş olan suç HAGB'ye engel oluşturacak ve sanık hakkında birden fazla HAGB kararı verilmesi önlenecektir.

\footnotetext{
Ahmet Hulusi Akkaş, Bir Güvenlik Tedbiri Türü Olarak Belli Hakları Kullanmaktan Yoksun Bırakılma (Hak Yoksunlukları), Adalet Yayınevi, 2021, s. 199.

31 Ayrıca bkz. Balo, s. 179; Yenisey/Nuhoğlu, s. 805.

32 Y. 3. CD, E. 2014/19721, K. 2014/41611, 15.12.2014. Aynı yönde Şen/Maviş, s. 18.

33 Şahin/Göktürk, s. 197.

34 Şahin/Göktürk, s. 197.
} 
Adli sicil arşiv kaydına alınan mahkumiyetler, sonraki suçta HAGB engeli olmaya devam ederken ${ }^{35}$, adli sicil bilgilerinin silinme koşulları oluştuğunda önceki mahkumiyet hükmünden bahsedilemeyeceğinden, CMK m. 231/6-a açısından sorun oluşmayacaktır. ${ }^{36}$

\section{Somut ceza sınırı}

CMK m. 231/5 uyarıca, sanığa yüklenen suçtan dolayı yapılan yargılama sonunda hükmolunan ceza, iki yıl veya daha az süreli hapis ya da adli para cezası ise HAGB uygulanabilir. Görüldüğü üzere, somutlaştırılmış hapis cezasında süre sınırı varken, adli para cezasında ${ }^{37}$ herhangi bir miktar sınırı öngörülmemiştir. ${ }^{38}$

Mahkeme tarafından sanık hakkında hem hapis, hem adli para cezasına karar verilmişse HAGB uygulanıp uygulanamayacağı tartışılmalıdır. Kanun metninde ceza türleri arasında "veya" ibaresinin kullanımı tereddüt doğursa da, ilgili fikradaki kullanımın ceza tür ve sınırlarını belirtmekten ibaret olduğu kabul edilmelidir. O halde sanık hakkında hem hapis, hem adli para cezasına karar verilmiş ve hapis cezasının süresi iki yıl ya da daha az ise

35 Aras, s. 74; Dülger, s. 938. Aksi görüşte Mustafa Özen, Öğreti ve Uygulama Işı̆̆ında Ceza Muhakemesi Hukuku, 2. Bask1, Adalet Yayınevi, 2018, s. 1038. Anılan durumun HAGB uygulamasını son derece sınırlayacağı görüşünde Sarıgül, s. 147.

36 Y. 3. CD, E. 2011/8-460, K. 2012/230, 12.06.2012. Aksi görüşte Şen/Maviş, s. 95.

37 CMK m. 231/5'te yer alan adli para cezas1, TCK m. 52 kapsamında belirlenen yaptırım olup, seçenek yaptırım (TCK m. 50) değildir, Demirbaş, s. 702.

38 §59 StGB hükmünde ise ceza nisabı çok düşük tutulmuş, hafif ağırlıktaki suçlar (Vergehen) uygulama kapsamına alınmıştır. §59 StGB hükmüne, ancak yüz seksen gün birimine kadar adli para cezasına mahkumiyetlerde başvurulabilir. Hapis cezalarında ve hapis cezasıyla birlikte ya da başlıca hükmedilen güvenlik tedbirlerinde §59 StGB uygulanmaz, bkz. Thomas Fischer, Strafgesetzbuch, 66. Bask1, C.H.Beck, 2019, §59 Rn. 2; MüKoStGB/ Groß/Kulhanek, § 59 Rn. 11. Bu yönüyle §59 StGB'da öngörülen yaptırım, Alman Ceza Hukukundaki en hafif yaptırımlar arasında yer alırken, bir ceza veya güvenlik tedbiri niteliğinde olmayıp, kendine has bir hukuki niteliği haizdir, bkz. Beck'sche Online Kommentare, Strafgesetzbuch, 48. Edition-1.2.2021, (BeckOKStGB/Heintschel-Heinegg), $\S 59$ Rn. 4; S/S-Kinzig, §59 StGB Rn. 3. Alman Ceza Hukuku doktrininde; sanık lehine görünen §59 StGB hükmünün çok sınırlı uygulandı̆̆ı, günümüz ihtiyaçlarını gözetmediği, ceza nisabı artırılarak ya da kapsamı genişletilerek kurumun daha yaygın kullanımın önünün açılması ve bu amaçla yasa değişikliği yapılması gerektiği yönünde görüşlerin paylaşıldığ belirtilmelidir, bkz. Christian Kropp, "Ist die Verwarnung mit Strafvorbehalt noch zeitgemäß?", 2004, ZRP, s. 241. Aynı kanaat ve beklentiyi paylaşmakla birlikte, kurumun revize edilmesinin sadece sanığı değil, cezayı bireyselleştirmekle görevli mahkeme için de elzem olduğu yönünde Frank Füglein/Pascal Lagardère, "Geld habe ich keines, aber arbeiten kann ich- Die Verwarnung mit Strafvorbehalt”, 2013, ZRP, s. 48. 
HAGB mümkün görülmelidir. ${ }^{39}$ Kasten işlenen suçta cezayla birlikte güvenlik tedbirine hükmedilmesi de, HAGB kararına mani değildir. ${ }^{40}$

Ceza sınırlarına ilişkin açıklamalarda tartışılması gereken diğer husus, birden fazla suç hakkında mahkumiyet kararı verilmesi ihtimalidir. Sanık hakkında, aynı dava kapsamında birden fazla suç için iki yıl veya daha az süreli hapis ya da adli para cezasına hükmedilmişse HAGB uygulanabilecek midir? Konuyla alakalı olarak kanunda açık bir düzenleme yoktur. Yargıtay, kanaatimizce isabetli olarak, HAGB'nin doğurduğu sonucu dikkate alıp düşme kararı ile ilgili yasal sonuçları kıyaslamış ve HAGB açısından her bir suç için ayrı değerlendirme yapılarak sonuca varılması gerektiğine hükmetmiştir. ${ }^{41}$ Zincirleme suçta ise kişiye tek ceza verileceğinden, somut ceza üzerinden değerlendirme yapılmalıdır. ${ }^{42}$ Ancak bu anılan olasılıklar, sanığın suç işleme eğilimi yönünden (sübjektif koşul) dikkate alınmalıdır. ${ }^{43}$

\section{Zararm giderilmesi}

Onarıcı adaletin yansıması olarak, HAGB için aranan diğer bir şart, suçun işlenmesiyle mağdurun veya kamunun uğradığı zararın aynen iade, suçtan önceki hale getirme veya tazmin suretiyle tamamen giderilmesidir (CMK m.231/6-c). ${ }^{44}$

CMK m. 231/6-c kapsamındaki "zarar" kavramıla; varsayımsal olmayan, somut nitelikteki ${ }^{45}$ maddi zararlar kastedilmektedir. ${ }^{46}$ HAGB açısından, mağdurun manevi zararının karşılanması şart değildir. ${ }^{47}$ Bununa

39 Özgenç, s. 714; Şahin/Göktürk, s. 196; Yenisey/Nuhoğlu, s. 798. Kanun koyucu, yasal düzenlemede HAGB için özel suç tiplerine münhasır farklı koşullar öngörebilir. Kullanmak için uyuşturucu veya uyarıcı madde satın almak, kabul etmek veya bulundurmak ya da uyuşturucu veya uyarıcı madde kullanmak suçu (TCK m. 191) buna örnektir.

40 Dülger, s. 940.

41 Y. CGK, E. 2008/11-250, K. 2009/13, 03.02.2009. Ayıca bkz. Gökcen/Balc1/Alşahin/Çakır, s. 632; Karakehya, s. 564; Yenisey/Nuhoğlu, s. 798; Zafer, s. 715.

42 Özen, s. 1036.

43 Gökcen/Balc1/Alşahin/Çakır, s. 632; Öztürk, s. 646; Yener Ünver/Hakan Hakeri, Ceza Muhakemesi Hukuku, 16. Bask1, Adalet Yayınevi, 2019, s. 678.

44 Timur Demirbaş, Ceza Hukuku Genel Hükümler, 15. Bask1, Seçkin Yayınevi, 2020, s. 703; Mahmut Kaplan, "Onarıcı Adalet ve Türk Ceza Hukukuna Yansımaları”, 2015, 5(1), AkdHFD, s. 78.

45 Aras, s. 75; Artuç/Hırsl1, s. 325; Dülger, s. 939; Taşdemir, s. 43.

46 Zararın tespitinde suç anının dikkate alınması gerektiği görüşünde Özen, s. 1040.

47 “... zarar yönünden, kanaat verici basit bir araştırma ile belirlenecek maddi zararların esas 
birlikte, CMK m. 231/6-c'ye dayanan zarar tazminin aynı olay ve sanık hakkında manevi tazminat davasına engel oluşturmadığı vurgulanmalıdır. ${ }^{48}$ Keza maddi zararının eksik kalan kısım için de, özel hukuk hükümlerine göre maddi tazminat davası açılabilir. ${ }^{49}$

Suç sonucunda herhangi bir maddi zarar doğmamışsa, HAGB için zararın tazmini koşulu aranmaz. ${ }^{50}$ Haliyle, tehlike suçuna ilişkin yargılamada HAGB kurumu işletilebilir. ${ }^{51}$ Mağdurun kendisine ya da ölümü sonras1 mirasçılarına ulaşılamadığ 1 hallerde ise, suçun konusu ele geçirilmişse, artık zarar tazmini aranmadan HAGB kararı verilebileceği, aksi halde HAGB'nin uygulanamayacağ ifade edilmektedir. $^{52}$

Mağdurun ya da kamunun zararı, sanık veya onun adına üçüncü kişi tarafından giderilebilir. ${ }^{53}$ Birden fazla sanığın yer aldığı dosyada mağdurun zararının sanıklardan biri tarafından karşılanması halinde, diğer sanıkların zararı kabul etmelerinin, kendileri açısından verilecek HAGB kararında şart olduğu savunulmaktadır. ${ }^{54}$ Kanaatimizce burada zararın objektif olarak giderilmesi yeterlidir, ek bir koşul aranmamalıdır. ${ }^{55}$

Zararı karşılayan ödeme tek seferde yapılamıyorsa, sanık hakkında

alınması, manevi zararların bu kapsama dahil edilmemesi gerektiği”, Y. CGK, E. 2008/11250, K. 2009/13, 03.02.2009; CGK, E. 2012/2-1418, K. 2013/424, 22.10.2013. Aynı yönde Aras, s. 75; Artuç, s. 120; Centel/Zafer, s. 876; Dülger, s. 939; Demirbaş, s. 703; Güngör/ Okuyucu-Ergün, s. 1955; Özbek/Doğan/Bacaksız, s. 707; Öztürk, s. 648; Parlar, s. 16; Şen/ Maviş, s. 29; Ünver/Hakeri, s. 681; Yalçın, s. 210; Yenisey/Nuhoğlu, s. 800. Kanunda açıkça maddi-manevi zarar ayrımı yapılmadığından, manevi zararın da şart kapsamında mütalaası gerekir, bkz. Karakehya, s. 567; İpek, s. 178. CMK hükmünün maddi-manevi zararlar şeklinde anlaşılmaya müsait olduğu, mağdurun zararın tazmini için ayrıca özel hukuk mahkemelerine yönlendirilmesinin HAGB kurumunun amaçlarından olan onarıcı adalet ile bağdaşmadığı görüşünde Balo, s. 195.

48 Y. 11. CD, E. 2016/8334, K. 2018/7310, 29.06.2018. Ayrica bkz. Centel/Zafer, s. 877; Dülger, s. 939; Özgenç, s. 718; Yenisey/Nuhoğlu, s. 800.

49 Dursun, s. 156; Kumbasar, s. 184; Özen, s. 1040; Özgenç, s. 718; Şen/Maviş, s. 33.

50 Artuç, s. 120; Centel/Zafer, s. 877; Demirbaş, s. 703; Dülger, s. 938; Şahin/Göktürk, s. 199; Ünver/Hakeri, s. 682.

51 Centel/Zafer, s. 877; Demirbaş, s. 703; Özen, s. 1039; Şahin/Göktürk, s. 199.

52 Kumbasar, s. 185.

53 Güngör/Okuyucu-Ergün, s. 1957; Soyaslan, s. 446; Ünver/Hakeri, s. 682; Yenisey/Nuhoğlu, s. 800 .

54 Aras, s. 76; Kumbasar, s. 183. Ödemeye katılmayan sanıklar hakkında HAGB uygulanamayacağı yönünde Epözdemir, s. 214.

55 Ayrıca bkz. Özen, s. 1041. 
mağdura veya kamuya verdiği zararı denetim süresince aylık taksitler halinde ödemek suretiyle tamamen gidermesi koşuluyla da HAGB kararı verilebilir (CMK m. 231/9).

Zararın giderilmesi bakımından, gerek CMK m. 231, gerek başka yasal kurumlar açısından (mesela CMK m.171) kanunda açık bir belirleme olmamasına rağmen, zarar konusu aynen iade edilebiliyorsa, öngörülen telafinin amacına binaen öncelikli olarak aynen iadenin gerçekleştirilmesi gerekir.

CMK m. 231/6-c ile etkin pişmanlık ilişkisinde; örneğin, TCK m. 168 kapsamında sanığın, malvarlığına karşı işlenen suçta oluşan zararı bizzat pişmanlık göstererek aynen geri verme veya tazmin suretiyle tamamen gidermesi halinde cezada indirim uygulanmaktadır. ${ }^{56}$ Etkin pişmanlık nedeniyle ceza indirimine gidildikten sonra, sanık hakkında HAGB karar1 verilmesinin mümkün olduğu belirtilmelidir. ${ }^{57}$

Zararın belirlenmesi ve giderilmesi konusunda mağdurun rızasına ilişkin yasal bir düzenleme yapılmamıştır. CMK m 231/6 kapsamında, ceza mahkemesi tarafından tespit edilen zararın karşılanması yeterlidir, mağdurun ekonomik mağduriyetinin devam edip etmediği önemsizdir. ${ }^{58} \mathrm{Bu}$ sebeple doktrinde, yasal eksikliğin giderilmesi ve sanık ile mağdurun anlaşması ile zararın giderilmiş olduğunun benimsenmesi; bu noktada, ödenen tazminatın mağdur tarafından kabul edilip edilmediğinin araştırılması gerektiği, mağdurun sözlü ya da kendisinden sadır olan yazılı beyanıyla bu hususun ispat edilebileceği ifade edilmektedir. ${ }^{59}$

ÇKK m. 23'e göre, çocuğa yüklenen suçtan dolayı yapılan yargılama sonunda, CMK'daki koşulların varlığı halinde, mahkemece HAGB kararı verilebilir. İlgili hükümde CMK m. 231'deki koşulların aynen tatbiki kabul edildiğinden, çocuk hakkında tesis edilecek HAGB için de doğan zararın

\footnotetext{
56 Özgenç, s. 717.

57 Y. CGK, E. 2014/4-567, K. 2015/11, 24.02.2015.

58 "Suçun işlenmesiyle mağdurun veya kamunun uğradığı zararın, aynen iade, suçtan önceki hale getirme veya tamamen giderilmesinde zarar yönünden, kanaat verici basit bir araştırma ile belirlenecek maddi zararların esas alınmast ... gerektiği”, Y. CGK, E. 2008/11-250, K. 2009/13, 03.02.2009; CGK, E. 2012/2-1418, K. 2013/424, 22.10.2013; Dülger, s. 938.

59 Zafer, s. 717. Mağdurun rızasının aranmaması, onarıcı adalet anlayışıyla çelişirir, bkz. Akyıldız, s. 69.
} 
giderilmesi şarttır. ${ }^{60}$

\section{B. Sübjektif Şartlar}

\section{Sanık hakkındaki kanaat}

HAGB kararının uygulanabilmesi için, sanığın şahsına bağlı koşullar da oluşmalıdır. Bunlardan ilki, sanığın mahkeme nezdinde bıraktığı izlenimdir. Öyle ki mahkeme, sanığın kişilik özellikleri ile duruşmadaki tutum ve davranışlarını göz önünde bulundurarak yeniden suç işlemeyeceği hususunda kanaate varmalıdır. Duruşmadaki izlenim elbette somut ve sınırlı gözleme dayanır. "Kişilik özellikleri" bakımından ise, sadece muhakeme sürecindeki hal ve hareketler değil, sanığın adli sicil kaydı ${ }^{61}$, sosyal çevre ile uyumu, hatta gerektiğinde bir disiplin cezası alıp almadığı gibi hususlar birlikte değerlendirilmelidir. ${ }^{62}$ Çünkü burada aranan şart, sadece duruşma sırasındaki kişisel tutum ve davranışlarla yetinilmeye müsait değildir. ${ }^{63}$ Yargıtay da, sanığın kişilik özelliklerine göre yeniden suç işleyip işlemeyeceği yönündeki nihai kanaatin soyut ifade ve gerekçeye dayandırılmasını yetersiz görmektedir. ${ }^{64}$ Ayrıca, iştirak halinde işlenen suçlarda her bir suç ortağının kişilik özelliklerinin ayrı analiz edilmesi gerektiği unutulmamalıdır. ${ }^{65}$

\section{Sanığın kabulü}

\section{a. Genel olarak}

22.07.2010 tarih ve 6008 sayılı Kanun ile yapılan değișiklikle, sanığın kabul etmemesi halinde HAGB kararı verilemeyeceği kabul edilmiştir (CMK m. 231/6-son cümle). ${ }^{6}$

\footnotetext{
60 Ünver/Hakeri, s. 682.
}

${ }_{61}$ Adli sicil kaydının silinmesine ilişkin koşulların oluşması sebebiyle adli sicilden silinen önceki mahkumiyetler CMK m. 231/6-a yönünden bir engel oluşturmasa da, kişinin suç işleme eğilimi yönünden yapılan değerlendirmeye esas alınabilir, Y. CGK, E.2010/4-71, K. 2010/76, 06.04.2010.

62 Dursun, s. 155.

63 Sarıgül, s. 152; Yenisey/Nuhoğlu, s. 799. Karş. Aras, s. 77; Öztürk, s. 648.

64 Y. CGK, E. 2011/253, K. 2012/117, 27.03.2012.

65 Ünver/Hakeri, s. 680.

666008 sayıll Kanun Geçici Madde 2'de, bu Kanunun yürürlüğe girdiği tarihe kadar hakkında HAGB kararı verilmiş olanların, bu Kanunun yürürlük tarihinden itibaren on beş gün içinde mahkemeye başvurmaları halinde, mahkemece bu kararının geri alınacağı ve CMK m. 231/7'deki kayıtla bağlı olmaksızın başvuruda bulunan sanık hakkında yeniden hüküm kurulacağı belirtilmiştir. Zaman açısından artık bu hükmün uygulanması 
HAGB kararının sanığın kabulüne bağlanması yönündeki yasa değişikliğinin temelinde, -ileride detaylı şekilde inceleneceği üzere-, HAGB kararına itiraz halinde merciin sadece kurumun yasal şartları üzerinden inceleme yapması, böylece beraat ya da ceza verilmesine yer olmadığına dair kararın verilmesi gereken bir dosyanın dahi denetlenememesi tehlikesinin doğması, gerekçe olarak gösterilmiştir. ${ }^{67} \mathrm{Bu}$ yönüyle sanığın kabulü, aklanma hakkı kapsamında sunulan bir imkan olarak değerlendirilebilir. ${ }^{68}$ Buna karşın ilgili kabul şartının benimsenmesiyle, sanık harici diğer süjelerin hak arama özgürlüğünün dikkate alınmadığı tespit ve eleştirisi dile getirilmektedir. ${ }^{69}$

Doktrinde, HAGB'nin reddedilmesi sebebiyle hükmün açıklanması, fakat kanun yolunda hükmün bozulması sebebiyle yeniden yarg1lama yapılmas1 durumunda, sanığın yeniden HAGB isteyemeyeceği, haliyle HAGB kararı verilemeyeceği ifade edilmektedir. ${ }^{70}$ Kanaatimizce, hem kurumun amacı ve sanık hakları, hem de bozmadan sonra serbestlik ilkesi gereğince bu görüş isabetli değildir. Bozmadan sonraki yargılamada HAGB için aranan koşullar ve sanığın kabulü dahilinde HAGB uygulanabilir.

HAGB'yi kabul edip etmediği sorusuna karşı sessiz kalan sanı̆̆ın, lehe olduğundan bahisle HAGB'yi kabul etmiş sayılamayacağ 1 belirtilmektedir. ${ }^{71}$ Gerçekten, HAGB'yi her koşulda lehe bir kurum olarak görmek doğru olmadığ 1 gibi, sükutun kabule eşdeğer olması için kanunen açık bir düzenlemeye ihtiyaç vardir.

söz konusu olmamakla birlikte, daha önce HAGB kararı verilmiş olmasına rağmen, yeni hükümde erteleme ya da kısa süreli hapis cezasına seçenek yaptırımlara çevirme kararının verilebilmesine imkan tanındığ $\breve{ }_{1}$ ifade edilmelidir.

67 Şahin/Göktürk, s. 202; Akif Yıldırım, "Mayınlı Bir Alan: Hükmün Açıklanmasının Geri Bırakılması Kararının Denetimi”, 2018, 11, Uyuşmazlık Mahkemesi Dergisi, s. 450. Bu minvalde doktrinde, sanığın kabulü şartıyla HAGB kurumunun yargılama makamlarınca kötüye kullanılmasının önüne geçildiği ifade edilmektedir, Toroslu/Feyzioğlu, s. 365. Ayrıca, uygulamada sanık dinlendikten sonra CMK m. 196 gereği sanığın duruşmadan bağışık tutulmasının doğurduğu hukuki sonuçların dikkate alınarak ilgili şartın ihdas edildiği belirtilmektedir, Taner, AnkBD, s. 294. Doktrinde Şen/Maviş de, esasen HAGB uygulamasının şartlar dahilinde re'sen tatbikinin doğru olduğunu, ama uygulamadaki sıkıntılar sebebiyle bu koşulun öngörüldügünü vurgulamaktadır, Şen/Maviş, s. 37.

68 Özbek/Başbüyük, s. 8 .

69 Özbek/Başbüyük, s. 8.

70 Yurtcan, s. 565.

71 Şen/Maviş, s. 38; Yalçın, s. 196. Aksi görüşte Rezan Epözdemir, Hükmün Açıklanmasının Geri Bırakılmas1, 2. Bask1, Adalet Yayınevi 2017, s. 103. 
Sanığın kabulünün HAGB açısından şart olması konusunda, suç fiili neticesinde ortaya çıkan maddi zararın giderilmesi ile kabul beyanının birlikte yorumlanması düşünülebilir. Fakat önemle belirtilmelidir ki, maddi zararın sanık tarafından giderilmesi tek başına HAGB'nin kabulü anlamına gelmemeli ve sanığa mutlaka bu konudaki iradesinin ne olduğu açıkça sorulmalıdır. ${ }^{72}$

\section{b. Müdafiin rolü}

CMK m. 231/6-son' da yer alan koşul lehte bir düzenleme görünümünde olmakla birlikte; bu şartın icrası sırasında, isnat olunan suçun mahkeme tarafindan sabit görüldügü ${ }^{73}$ ve sanık hakkında en az iki yıl hapis ve/veya adli para cezası yaptırımının takdir edildiği unutulmamalıdır. Bu olgu dikkate alındığında, sanığın kabulünde zorunlu müdafi şartının olmaması, kanaatimizce ciddi bir eksikliktir. Çünkü sanığın, HAGB'nin hukuki ayrıntılarını bilmemesi ve muhakeme sürecinde kendisini pozisyon itibarıyla baskı altında hissetmesi halinde, kendisinden sadır olan iradenin sihhati etkilenecektir. ${ }^{74}$ Bu olumsuzluk, ancak müdafi yardımıyla dengelenebilir. ${ }^{75}$ HAGB'nin kabul edilmesi de, aslında sanığın kendisi hakkında tesis edilen mahkumiyet hükmüne, yani isnat olunan suçun sabit görüldügüne katılma anlamı taşır ve bunun tek başına sanık tarafından tahlil edilmesini beklemek güçtür. ${ }^{76}$ Diğer yandan, HAGB'nin hukuki etkilerinin tam olarak anlaşılamaması sebebiyle reddedilmesi ve sanığın aleyhe sonuçlarla karşılaşması da olasıdır. ${ }^{77} \mathrm{O}$ halde, sanığın iradesine bağlanan emsal kurumlardan seri muhakeme usulünde olduğu gibi (CMK m. 250/3), HAGB'nın uygulanmasına dair iradenin müdafi huzurunda açıklanması, yasada açıkça şart koşulmalıdır. Bu doğrultuda, CMK m. 231/6-son cümlesinin "Hükmün açıklanmasının geri bırakılması, sanık tarafindan müdafi huzurunda kabul edildiği takdirde uygulanabilir" şeklinde yeniden kaleme alınması isabetli olacaktır. Ne var ki uygulamada, duruşmaya

72 Centel/Zafer, s. 877; Güngör/Okuyucu-Ergün, s. 1958; Zafer, s. 717.

73 Güngör/Okuyucu-Ergün, s. 1955; Şahin/Göktürk, s. 195.

${ }_{74} \mathrm{Bu}$ durum, aynı zamanda silahların eşitliğiyle doğrudan ilgilidir, bkz. Fahri Gökçen Taner, Ceza Muhakemesi Hukukunda Adil Yargılanma Hakkı Bağlamında Çelişme ve Silahların Eşitliği, Seçkin Yayınevi, 2019, s. 179. Ayrıca bkz. Holm Putzke/Jörg Scheinfeld, Strafprozessrecht, 3. Bask1, C.H.Beck Yayınevi, 2011, s. 81.

75 Hans-Heiner Kühne, Strafprozessrecht, 8. Bask1, C.F.Müller,2010, §9 Rn. 170; Putzke/ Scheinfeld, s. 81; Taner, Silahların Eşitliği, s. 179.

76 Kaya, s. 435. Sanığa tanınan hakkın ilerleyen süreçte sanık aleyhine kullanılmasının genel hukuk kaidelerine aykırı olacağı görüşünde Özen, s. 1046.

77 Benzer hukuki endişe için bkz. Karakehya, s. 563. 
katılmayan sanığın ${ }^{78}$, HAGB'yi zımnen kabul etmiş olduğu benimsenmektedir ki, dile getirdiğimiz çekinceler karşısında bu tutumu isabetli görmek mümkün değildir. ${ }^{79}$ Diğer yandan Yargıtay' $1 n^{80}$, müdafiin bulunduğu duruşmada özel vekaletname şartıyla müdafiin iradesini kabul beyanı için yeterli sayması doğru değildir. ${ }^{81}$ Müdafi yardımı hukuken ne kadar gerekliyse, sanığın kabul ya da ret iradesini bizzat açıklaması da o kadar kaçınılmazdır.

\section{c. İradenin açıklanma anı ve mahkemenin pozisyonu}

$\mathrm{Bu}$ bölümde üzerinde durulması gereken diğer bir tartışmalı nokta, sanığın işlediği suçun mahkeme tarafindan sabit görülmesidir. Mahkeme, elbette bu kanaatini duruşmayı sonlandırırken, yani hüküm aşamasında açılamak zorundadır (CMK m. 223). Nitekim tüm muhakeme işlemlerinin esas amacı, iddia olunan vaka hakkında mevcut deliller değerlendirilerek maddi gerçeğe ulaşmak ve bu yönde hüküm tesis etmektir. Fakat HAGB hakkındaki soru evresinde henüz yargılama sona ermemiştir. Yargılama devam ederken sanığa HAGB'yi kabul edip etmediğinin sorulması, mahkeme nezdinde sanığın suç işlediğinin sabit görüldüğünün yansımasıdır. $\mathrm{Bu}$ yansıma neticesinde hakimin, henüz nihai karar öncesinde dava konusu olayla ilgili ulaştığ1 sonucu paylaşarak "ihsas-1 rey"de bulunduğu iddia edilebilir. ${ }^{82}$ Nitekim CMK m. 24/1'e göre, hakimin davaya bakamayacağı hallerde reddi istenebileceği gibi, tarafsızlı̆̆ını şüpheye düşürecek diğer sebeplerden dolayı da reddi istenebilir. Acaba hakimin sanığa karşı HAGB konusundaki iradesini

78 Emsal düzenleme $\$ 59$ StGB kapsamında, davanın sanığın yokluğunda yürütülebilmesi mümkündür ( $\$ 232$ StPO). Ancak kurumun uygulama kapsamı dikkate alındığında, ceza nisabının CMK m. 231/5'e nazaran çok düşük olduğu unutulmamalıdır. Ayrıca anılan durumda sanık, belli koşullarda istinaf (Berufung) başvurusunda bulunma hakkına sahiptir, bkz. Kühne, §63 Rn. 1041.

79 Y. 4. CD, E. 2012/31570, K. 2013/17818, 06.06.2013. Yargitay'ın bu değerlendirmeyle, yasada öngörülen usulü son derece geniş yorumladığı görüşünde Ünver/Hakeri, s. 683.

80 Y. CGK, 2015/225, 2019/616, 22.10.2019.

81 Akyıldız, s. 77. Doktrinde Özen'e göre, sanı̆̆ın müdafi ile temsil edilmesi durumunda, HAGB'nin kabul edilip edilmediği mutlaka müdafie de sorulmalıdır. Hatta yazara göre, zorunlu müdafi olarak görev yapan temsilcinin iradesi ile sanığın iradesi çelişirse, kurumun hukuki sonuçlarına daha hakim olan müdafin iradesine öncelik tanınmalıdır, Özen, s. 145. Artuç/Hırslı'ya göre, müdafi HAGB'ye dair beyanda bulunsa bile, kanun metninde sanığın iradesinin esas alındığı açıktır, Artuç/Hırslı, s. 327. Şen/Maviş ise, CMK m. 216 ve m. 226/4'e dayanılarak HAGB konusundaki iradenin müdafiden beklenebileceğini; ancak öncelikli iradenin sanığa ait olduğunu; buna karşın, sanığa kanuni temsilci atanmışsa, artık temsilcinin iradesinin ön plana çıktığını vurgulamaktadır, Şen/Maviş, s. 37.

82 Benzer hukuki endişe için bkz. Öztürk, s. 645. 
sorması, tarafsızlığı şüpheye düşürecek sebep olarak algılanabilir mi? Hakimin HAGB kararının uygulanabilirliği konusundaki sorusu, içeriğinde suçun sabit görülmesini barındırsa da ${ }^{83}$, tarafsızlığı şüpheye düşürecek mahiyette değildir. Çünkü HAGB'nin sanık tarafından kabul edilmemesi, takdir edilen yaptırımın HAGB dışındaki kurumlar gözetilerek uygulanması sonucunu doğurur.

Özetle; HAGB müessesesi, hükmün gizli tutulması anlamında değildir ${ }^{84}$ ve mahkeme, hükmü tüm yasal unsurlarıyla ve aleni şekilde açıklayıp, sanığa HAGB konusundaki iradesini sormalıdır. ${ }^{85}$ Karar evresinden önce, sanığa HAGB konusundaki iradesinin sorulmasının hukuken tasvip edilmeyeceği kuvvetle vurgulanmalıdır. ${ }^{86}$ Ayrıca, henüz yargılamaya devam olunurken sanığın kendi iradesiyle HAGB'yi reddettiğini söylemesi durumunda, mahkeme tarafından yine HAGB şartları değerlendirilmeli ve son aşamada sanığa yine HAGB'yi kabul edip etmediği sorusu yöneltilmelidir. ${ }^{87}$

\section{Sanığın kabul beyanının delil değeri}

Sanı̆̆ın HAGB uygulamasını kabul etmesine dair beyanının suçu ikrar anlamına gelip gelmeyeceği, tartışılması gereken bir sorun olarak karşımıza çıkmaktadır.

Sanık hakkında beraat ya da ceza verilmesine yer olmadığına dair karar verilmesi imkanı varken HAGB'ye imkan yoktur. Kuruma başvurulması, isnat olunan suçun sanık tarafından işlendiğinin sabit olduğunu gösterir. $\mathrm{O}$ halde sanığın HAGB'ye ilişkin kabul beyanı, esasında suçu işlediğini ikrar

83 Sanık sıfatının devam etmesi ve masumiyet karinesine dayanarak aksi kanaatte Şen/Maviş, s. 15.

84 Madde gerekçesi (5560 sayılı Kanun m. 23).

85 Gökcen/Balcı/Alșahin/Çakır, s. 635; Güneș, s. 140; Kumbasar, s. 46; Taner, AnkBD, s. 296; Temur, s. 140; Yıldırım, s. 437. Alman Hukuku bakımından aynı yönde Fischer, §59 Rn. 2. Buna karşın doktrinde Centel/Zafer, CMK m. 231/5 kapsamında karar verilirken öngörülen mahkumiyet hükmünün açıklanmasının HAGB kurumunun niteliği ile bağdaşmayacağı, kurumu hapis cezasının ertelenmesi gibi cezanın infazına yönelik bir niteliğe evireceği, mahkumiyete ilişkin hususların aleni duruşmada paylaşılmasıyla HAGB'nin felsefi temellerinden uzaklaşılacağı ve kurumun adeta cezaevlerini rahatlatan bir araca dönüşeceği görüşündedir, Centel/Zafer, s. 871.

86 Akyıldız, s. 78; Artuk/Gökcen/Alşahin/Çakır, s. 843; Güner, s. 198; Güngör/OkuyucuErgün, s. 1959; Karakehya, s. 565; Şen/Maviş, s. 39; Taner, AnkBD, s. 296; Taşdemir, s. 63; Ertuğrul Ünal, "Uzlaştırma ve Hükmün Açıklanmasının Geri Bırakılması Kurumlarının Masumiyet Karinesi Bağlamında Değerlendirilmesi”, 2018, 17(1), İKÜHFD, s. 212. Karş. Artuç/Hırsli, s. 327.

87 Şen/Maviş, s. 32. 
anlamındadır. ${ }^{88} \mathrm{Bu}$ hukuki tablonun ortaya çıkardığı sakıncayı gidermek adına ilk önerimiz, bu iradenin müdafi huzurunda açılanmasıdır. ${ }^{89}$ Burada ise ele alınması gereken iki esaslı problem göze çarpmaktadır: İlk problem, HAGB'yi kabul eden sanığın itiraz kanun yoluna başvuru hakkı ve başvuru halinde sanık açısından hukuki yarar meselesidir. Bu sorun, kanun yolunu incelediğimiz bölümde çözümlenecektir. Diğer problem ise, HAGB kararından sonra yasal nedenler sonucunda hükmün açıklanması ve bu hükme karşı kanun yoluna başvurulduktan sonra yapılan yargılamada, sanığın halihazırdaki kabul beyanının suçu ikrar gibi delil değeri taşıyıp taşımayacağıdır. Kanun yolu veya sonrasında görevli mahkemenin, sanığın daha önce HAGB'ye dair kabul beyanını suçu ikrar olarak delil kapsamında ele almasına yasal bir engel bulunmamaktadır. Ancak HAGB kurumunun uygulanabilirliği açısından öngörülen usul sebebiyle sanığın, kendi aleyhine olan böyle bir hukuki durumla karşılaşması, ilkesel açıdan sorun oluşturmaktadır. Böylece sanı̆̆ın kabul ya da ret beyanının özgür iradeye dayanması sakatlanmaktadır. O halde çözüm olarak; emsal düzenlemelerden CMK m. 250/10 gibi, HAGB kararına ilişkin kabul beyanının ikrar niteliği taşımadığı yasada açıkça yer almalıdır. Bu bakımdan CMK m. 231/6-son cümleden sonra şöyle bir cümle eklenebilir: "Sanığın, müdafii huzurunda hükmün açılklanmasının geri bırakılmasını kabul ettiğine iliş̧kin beyanı, takip eden veya aynı konu hakkındaki başka bir soruşturma ve kovuşturmada delil olarak kullanılamaz". Böylelikle sanığın iradesinin suçu ikrar endişesinden bağımsız olarak şekillenip açıklanmasına ilişkin koşullar yasal açıdan elverişli hale gelecektir.

Bu bölümde son olarak belirtelim ki, HAGB kararının sanığın kabulüne bağlanmasına ilişkin yasal düzenleme hakkında, Anayasa Mahkemesi'ne iptal davası açılmış, ancak Mahkeme oybirliğiyle davayı reddetmiştir. ${ }^{90}$

88 Aksi kanaatte Şen/Maviş, s. 31. Paylaştığımız endişeyi dile getiren Güneş, kurumun niteliği itibarıyla sanığın beyanın suçun kabulünden bağımsız olarak algılanması gerektiği görüşündedir, Güneş, s. 138.

89 Bkz. II B 2 b.

90 "Hükmün açılklanmasının ertelenmesine ilişsin olarak kanunda öngörülen tüm koşulların oluşması durumunda ceza hakiminin takdiri ile verilen hükmün açıklanmasının geri bırakılması kararl, itiraz konusu kuralın 231. maddeye eklenmesinden sonra sanığın talebine bağlı olarak verilebilecektir. Ceza sistemimizde yer alan hükmün açıklanmasının geri bırakılması kararının verilebilmesi koşullarına ilaveten getirilen ve sanığa kararı temyiz incelemesine götürebilme hakkı tanıyan kural, Anayasanın ve ceza hukukunun genel ilkelerine aykirı olmayıp, yasakoyucunun takdir yetkisi kapsamındadır. İtiraz konusu kuralda sanı̆̆ın kendi aleyhine beyanda bulunmaya zorlanması söz konusu olmadı̆̆ gibi, iptali istenilen kuralın 231. maddeye eklenmesinden sonra, saniğın iradesine önem verilerek, sanığın iradesi dışında hükmün açıklanmasının geri bırakılması müessesesinin uygulanması 
Mevcut yasal koşulları gözeterek yaptığımız değerlendirmeler çerçevesinde Mahkeme'nin vardığı nihai karara hukuken katılmıyor; ilgili şartın müdafi huzurunda yapılan irade açıklaması ve kabulün suçu ikrar anlamı taşımayacağ 1 kaydına yasa metninde açıkça yer verilmesi gerektiği yönündeki önerimizi yineliyoruz.

\section{Hükmün Açıklanmasının Geri Bırakılması Kararı Verilemeyecek Haller}

\section{Genel Olarak-Özel Suç Tipleri}

Anayasa m. 174'te koruma altına alınan inkılap kanunlarında yer alan suçlarla ilgili olarak HAGB uygulanmaz (CMK m. 231/14). Karşılıksız çek keşidesi suçunda da HAGB imkanı yoktur (5941 sayılı Çek Kanunu m. 5/10). Yine 5739 say1lı Kanun ile getirilen istisnalar ile 6222 sayılı Sporda Şiddet ve Düzensizliğin Önlenmesine Dair Kanun'da yer alan özel düzenleme dikkate alınmalıdır. $^{91}$

\section{Suçun Uzlaşmaya Tabi Olması}

Alternatif çözüm yolu olarak düzenlenen uzlaştırma kurumu, uygulama bakımından HAGB'ye göre önceliğe sahiptir. ${ }^{92}$ Uzlaştırmanın söz konusu olduğu durumda mahkeme, dosyayı uzlaştırma bürosuna göndermek zorundadır. Esas olarak soruşturma evresinde gündeme gelen uzlaştırmanın edimli ya da edimsiz olarak sonuçlanması halinde zaten bir kovuşturma evresinden bahsedilmeyecek, kovuşturmaya yer olmadığına dair karar verilerek soruşturma evresi sonlandırılacaktır (CMK m. 253/19). HAGB'ye göre öncelikli konumda olan uzlaştırma kurumu ise, kovuşturma evresinde uzlaştırmada karşımıza çıkmaktadır. "Mahkeme tarafından uzlaştırma" başlığ1 taşıyan CMK m 254/1'e göre, kamu davas1 aç1ldıtan sonra kovuşturma konusu suçun uzlaşma kapsamında olduğunun anlaşılması halinde kovuşturma

engellenmiştir. Sanığa, hükmün açıklanmasının geri bırakılması kararına karşı olduğunu beyan etme ve dolayısıyla hakkında verilen kararı temyiz incelemesine götürebilme imkânı veren kural, Anayasa'nın 38. maddesinin beşinci fikrasinda öngörülen, kendisini suçlama ve bu yolda delil göstermeye zorlanma olarak değerlendirilemez. Açıklanan nedenlerle, itiraz konusu kural Anayasa'nın 2., 36. ve 38. maddelerine aykırı değildir. Iptal isteminin reddi gerekir. Kuralın Anayasa'nın 5., 10., 11., 12. ve 13. maddeleri ile ilgisi görülmemiştir”, AYM, E. 2011/41, K. 2012/25, 16.02.2012 (RG: 13.10.2012, Say1: 28440).

91 HAGB kapsamı dışında bırakılan özel suç tipleri hakkında ayrıntılı inceleme için bkz. Yalçın, s. 122 vd.

92 Berrin Akbulut/Murat Aksan, Ceza Muhakemesi Hukukunda Uzlaştırma, 2. Bask1, Seçkin Yayınevi, 2019, s. 42. 
dosyası, uzlaştırma işlemlerinin yerine getirilmesi için uzlaştırma bürosuna gönderilir. Uzlaşma gerçekleştiği ve uzlaşma sonucunda sanığın edimini def'aten yerine getirmesi halinde mahkeme davanın düşmesine hükmeder (CMK m. 254/2). Edimin yerine getirilmesinin ileri tarihe birakılmas1, takside bağlanması veya süreklilik arz etmesi halinde; sanık hakkında, CMK m. 231'deki şartlar aranmaksızın HAGB kararı verilir (CMK m. 254/2). Bu karar verildikten sonra, uzlaşmanın gereklerinin yerine getirilmemesi halinde mahkeme tarafindan, CMK m. 231/11'de belirlenen şartlar aranmaksızın hüküm açıklanır (CMK m. 254/2).

Sonuç olarak, uzlaştırmaya tabi bir suç hakkında, ancak uzlaştırmanın olumsuz neticelenmesi sebebiyle yargılamaya devam olunmuşsa, hüküm aşamasında HAGB kararı (CMK m. 231/5) verilebilir.. ${ }^{93}$

\section{AİHM ve Anayasa Mahkemesi İçtihatları}

CMK m. 231/14 ve münhasıran özel kanunlarda yer alan bazı suçlar hariç, HAGB uygulanamayacak suçlar yönünden doğrudan suç tipini niteleyen herhangi bir düzenleme yapılmamıştır. Başka deyişle, bu kapsama giren suçlar prensip olarak objektif açıdan, ilgili suç için öngörülen ceza tür ve miktarına göre belirlenmiştir. O halde, yasa metnindeki ifade tahlil edildiğinde, dava konusu suç tipinden bağımsız olarak, mahkeme tarafından tespit edilen ceza miktarının CMK m. 231/5'te yer alan sınırlar içinde kalması halinde HAGB tartışılacaktır. Ne var ki bu noktada AİHM ve Anayasa Mahkemesi içtihatlarının dikkate alınması elzemdir. Nitekim AİHM, Avrupa İnsan Hakları Sözleşmesi'nin kötü muameleden korumaya yönelik amacı ve HAGB uygulamasının hükmü etkisiz bırakma sonucu doğurması gerekçesine dayanarak, bilhassa kötü muamele ve işkence içeren suçlarda HAGB kararı verilmesini Sözleşme hükümlerine aykırı bulmuştur. ${ }^{94}$ Anayasa Mahkemesi ise bireysel başvuru üzerine verdiği kararda, cinsel saldırı suçunun faili hakkında HAGB kararı verilmesinin Anayasa m. 17/3' ü$^{95}$ ihlal ettiğine hükmetmiştir. ${ }^{96}$

AİHM ve Anayasa Mahkemesi içtihatları dikkate alındığında; işkence,

\footnotetext{
93 Akbulut/Aksan, s. 42; Olgun Değirmenci, Onarıcı Adalet Uygulaması Olarak Ceza Muhakemesinde Uzlaştırma, Seçkin Yayınevi, 2020, s. 315.

94 Taylan/Türkiye kararı, B. No: 32051/09, 03.07.2012. Ayrıca bkz. Şahin/Göktürk, s. 200; Yenisey/Nuhoğlu, s. 798.

95 Anayasa m. 17/3: "Kimseye işkence ve eziyet yapılamaz; kimse insan haysiyetiyle bağdaşmayan bir cezaya veya muameleye tabi tutulamaz".

96 E.A. Başvurusu, Başvuru No: 2014/19112, 17.05.2018 (RG: 01.08.2018, Say1: 30496).
} 
kötü muamele ve cinsel saldırı suçlarında HAGB uygulamasına başvurulması AİHS ve Anayasa'nın ruhuna aykırı görülmüştür. Böylece, anılan suçlarda CMK m. 231'de yer alan objektif koşullar oluşsa bile HAGB kararı verilemeyecektir. Böylece HAGB açısından içtihat yoluyla yeni şartlar eklenmiş görünmektedir. ${ }^{97} \mathrm{Bu}$ tutum kabul edilebilir olmakla birlikte, aslında başka suçlarda da aynı etkinliğin gözlemlenmesi ve bu yönüyle HAGB'nin işlevsel olmadığı sonucuna varmak mümkündür. Nitekim emsal kararların dayanağını oluşturan Anayasa m. 17/3 hükmü, her suç açısından geniş yorumlanmaya müsaittir. Çünkü insan haysiyetiyle bağdaşma kriteri olarak mağdur ve toplum nezdinde bırakılan etki açısından kanunda somut düzenleme yapılmadıkça, söz konusu hukuki yaklaşım geniş yorumlanabilecektir. Bu anlamda, dava konusu olayın değerlendirilmesinde vücut dokunulmazlığ irade özgürlügü̈, şeref gibi temel insan haklarına karşı yönelen kasten yaralama, tehdit, hakaret suçlarında da, haksız saldırının karşılığında etkili bir yaptırım beklenir. Bu açıdan uygulamada sıklıkla karşılaşılan suçlar hakkında da HAGB uygulanmaması gerektiği pek tabii savunulabilir.

Mahkeme içtihatlarında belli suçlara özgü geliştirilen yorumun sonucu olarak kanaatimizce; CMK m. 231 kapsamına giren suçlar açıkça belirtilerek, HAGB için ceza miktarı üzerinden çizilen çerçeve daha somut hale getirilmelidir. ${ }^{98}$ Böylelikle, AİHM ve Anayasa Mahkemesi kararlarında vurgulan şekliyle AİHS ve Anayasa hükümleri ile uyumluluk sağlanabilir ve ayrıca mahkeme içtihatları arasında doğabilecek farklılıkların önü alınabilir.

\section{Hükmün Açıklanmasının Geri Bırakılması Kurumunun Zaman Bakımından Uygulanma Koşulları}

HAGB kurumunun zaman bakımından uygulanmasının analizinde, kurumun hukuki niteliği ve ilgili normatif düzenlemede yer verilen özel hükümler değerlendirilmelidir.

97 Yildırım, s. 469.

985728 sayılı Kanun ile yapılan değişiklik öncesinde HAGB, ancak şikayete tabi suçlar açısından mümkündü (5560 sayılı Kanun m. 23- CMK m. 231/14). İlgili koşula ilişkin gerekçe ise şu şekildeydi: “...söz konusu kurumun sağllklı bir şekilde uygulanabilmesi için, kapsamına giren suçların sinırlı tutulması düşünülmüş̧ür. Bu mülahazayla, 231 inci maddeye eklenmesi öngörülen beșinci fikradaki somut olayda hükmolunan hapis cezasına ilişkin iki yıllık sinır bir yıla indirilmiştir. Keza, ondördüncü fikrada yapılması önerilen değişiklikle, hükmün açıklanmasının geri bırakılması müessesesinin sadece soruşturulması ve kovuşturulması şikayete bağlı suçlarla ilgili olarak uygulanabilmesi amaçlanmıștır". Yapılan değişikliğin kurumun amacına aykırı düştüğü görüşünde Yurtcan, s. 564. 
Kanunilik ilkesinin doğal sonuçlarından biri, ceza hukuku kurallarının derhal uygulanmasıdır. ${ }^{99}$ Fakat suç ve cezaya ilişkin hükümler ile güvenlik tedbirlerinde, fail hakkında -zaman bakımından- uygulanabilecek birden fazla normun varlığ 7). ${ }^{100}$ Böylelikle, maddi ceza hukuku normları failin lehine olacak şekilde geriye yürür. ${ }^{101}$ Şekli ceza hukuku normları ise, kanunda aksine bir belirleme yapılmadıkça, failin leh veya aleyhine olmasına bakılmaksızın derhal uygulanır. ${ }^{102}$ İnceleme konumuz açısından, CMK m. 231/5'te öngörülen HAGB, fail tarafından işlenen fiil üzerinde herhangi bir etkisi olmayan, suçun unsurlarında değişiklik doğurmayan, ama failin cezalandırılmasını önleyen bir kurumdur. Burada düşme hükmü ile ortaya çıkan cezasızlık durumu, özel bir muhakeme işleminden ibarettir. Tek başına failin lehine olması, HAGB'nin maddi ceza hukuku normu olarak kabulünü gerektirmez. Sonuç olarak HAGB, bir ceza muhakemesi hukuku normudur ${ }^{103}$ ve bu nedenle kanun koyucunun ayrı ve açık iradesi olmadıkça kurum hakkındaki yasal değişikliklerin yürürlük bakımından geriye yürümesi doğru değildir. ${ }^{104}$

Yargıtay, HAGB'nin kesinleşmiş, infaz edilmekte olan ve hukuki yarar bulunması kaydıyla infaz edilmiş hükümlere de uygulanabileceği, kesinleşmiş hükümlerde kuruma ait objektif koşullar açısından dosya üzerinden, sübjektif koşullar bakımından ise duruşma açılarak değerlendirme yapılacă̆ ya da HAGB'nin reddi kararına karşı itiraz edilebileceği, kanaatindedir. ${ }^{105}$

99 M.Emre Tulay, "Kanunilik İlkesi Işı̆̆ında Ceza Kanunlarının Zaman Bakımından Uygulanması ve Delil Elde Etme Yöntemlerinde Zaman Bakımından Uygulanma Sorunu", 2016, 22(3), MÜHF-HAD, Prof. Dr. Cevdet Yavuz'a Armağan, s. 2720 vd.

100 Geçici ve süreli kanunla ilgili öngörülen istisna ayrı tutulmalıdır, bkz. TCK m. 7/4: "Geçici veya süreli kanunların, yürürlükte bulundukları süre içinde işlenmiş olan suçlar hakkında uygulanmasina devam edilir".

101 Özgenç, s. 141; Tulay, s. 2721.

102 Artuk/Gökcen/Alşahin/Çakır, s. 159 vd.; Koca/Üzülmez, s. 77.

103 Karakehya, s. 561. Hem maddi, hem şekli ceza hukuku ile irtibatı olan HAGB kurumunun muhakeme hukuku ile ilişkisinin daha yoğun olduğu ve zaman bakımından uygulama meselesinin bu doğrultuda çözümlenmesi gerektiği yönünde Özgenç, s. 723. HAGB kurumunun karma nitelikte bir hukuk normu olduğu görüşünde Dülger, s. 936; Gökcen/ Balcı/Alşahin/Çakır, s. 632; Güneş, s. 13; Kaya, s. 414; Kumbasar, s. 53; Öztürk, s. 645; Taşdemir, s. 9. HAGB'nin karma nitelikte olmasına karşın maddi ceza hukuku normu yönünün daha baskın olduğu görüşünde Aky1ldız, s. 68; İpek, s. 19. Kurumun maddi ceza hukuku normu olduğu görüşünde Aras, s. 72; Sarıgül, s. 132; Taner, AnkBD, s. 290; İhsan Baştürk, Hükmün Açıklanmasının Ertelenmesi, Adalet Yayınevi, 2014, s. 487.

104 Özgenç, s. 723. Aksi görüşte Gökcen/Balc1/Alşahin/Çakır, s. 632; Öztürk, s. 645.

105 Y. CGK, E. 2008/11-250, K. 2009/13, 03.02.2009. Ayrıca bkz. Ünver/Hakeri, s. 677. 
Oysa bu içtihadın hukuken doğruluğunu teyit edecek normatif bir düzenleme yoktur. ${ }^{106}$ Yüksek Mahkeme bu kararıyla, görünüşte sanık lehine bir tutum sergilerken, aslında yasama organına ait yetkiyi kullanmıştır. HAGB kurumunun zaman bakımından geriye yürütülerek kesinleşmiş ve hatta infazı tamamlanmış dosya üzerinde etki doğurması isteniyorsa, bunun içtihatlarla değil, yasal düzenlemeyle sağlanması şarttır. Neticeten, zaman bakımından uygulama açısından Yüksek Mahkeme içtihadının hukuken yerinde olmadığ bir kez daha vurgulanmalıdır. ${ }^{107}$

\section{HÜKMÜN AÇIKLANMASININ GERİ BIRAKILMASI KARARININ HUKUKİ ETKILERI}

\section{A. Sanık Açısından Getirilen Yükümlüllükler Bakımından}

\section{Zorunlu Denetim Süresi}

Kanun koyucu, HAGB kararında zorunlu bir denetim süresi öngörmüş, böylece sanık hakkında ceza içeren hükmün askıda beklemesi süreye bağlanmıştır. ${ }^{108}$ Denetim süresi kural olarak beş (CMK m. 231/8), suça sürüklenen çocuklarda ise üç yıldır (ÇKK m. 23). Denetim süresi içinde, kişi hakkında kasıtlı bir suç nedeniyle bir daha HAGB kararı verilemez (CMK m. 231/8). ${ }^{109}$ Yasa metnindeki "kasitlı bir suç nedeniyle" ibaresi tıpkı CMK m. 231/6'da olduğu gibi tartışmaya açık olup, bu şart yönünden kanaatimizce suçun işlenme anı esas alınmalıdır. ${ }^{110}$

Beş y1llık denetim süresi içinde bir y1ldan fazla olmamak üzere mahkemenin belirleyeceği süreyle, sanığın denetimli serbestlik tedbiri

106 Ünver/Hakeri, s. 677.

107 Ayrıca bkz. Ünver/Hakeri, s. 677.

108 Dursun, s. 158; Sarıül, s. 131; Şahin/Göktürk, s. 195; Toroslu/Feyzioğlu, s. 364; Yenisey/ Nuhoğlu, s. 801; Yurtcan, s. 784.

109 Doktrinde Centel/Zafer'e göre, esasında hukuki sonuç doğurmayan, teknik anlamda mahkumiyet niteliği taşımayan HAGB kararının, sonradan işlenen suçta aynı kurumun uygulanmasına engel olmaması beklenir. Ancak kanun koyucu CMK m. 231/8'de yer verdiği istisnayla, suçu işlediği sabit olan sanık hakkında birçok kez cezasızlık durumunun ortaya çıkmasını engellemiştir. Diğer yandan, bu düzenlemeyle birlikte HAGB'nin şartlı mahkumiyet olarak kabul edildiği de söylenebilir, Centel/Zafer, s. 876.

110 Doktrinde Özbek/Doğan/Bacaksız'a göre, kanun koyucunun bu hükümde yer verdiği şart muğlak bir ifade olup, "kasıtlı bir suç nedeniyle" denilerek hangi anın belirleyici olduğu tespit edilememektedir, Özbek/Doğan/Bacaksız, s. 707. Suça dair yapılan yargılamada hükmün verildiği anın dikkate alınması gerektiği görüşünde Akyıldız, s. 72; İzlem Uludaş, "Hükmün Açıklanmasının Geri Bırakılması Kurumunun ve 6545 Sayılı Yasa ile Getirilen Değişikliğin Değerlendirilmesi”, 2014, 6(56), FHD, s. 18. 
olarak; bir meslek veya sanat sahibi olmaması halinde, meslek veya sanat sahibi olmasını sağlamak amacıyla bir eğitim programına devam etmesine (CMK m. 231/8-a), bir meslek veya sanat sahibi olması halinde ise, bir kamu kurumunda veya özel olarak aynı meslek veya sanatı icra eden bir başkasının gözetimi altında ücret karşılığında çalıştırılmasına karar verilebilir (CMK m. 231/8-b). Sanığın belli yerlere gitmekten yasaklanmas1, belli yerlere devam etmek hususunda yükümlü kılınması ya da takdir edilecek başka yükümlülüğü yerine getirmesi denetim seçenekleri arasındadır (CMK m. 231/8-c). ${ }^{111}$ Burada dikkat çeken husus, denetim süresinin zorunlu, denetimli serbestlik tedbirinin ise ihtiyari olduğudur. ${ }^{112}$

\section{Kasıtlı Suç İşlememe Yükümlülüğü}

CMK m. 231/10'da yer alan "Denetim süresi içinde kasten yeni bir suç işlenmediği ve denetimli serbestlik tedbirine ilişsin yükümlülüklere uygun davranıldığı takdirde, açıklanması geri bırakılan hüküm ortadan kaldırılarak, davanın düsmesi kararl verilir" hükmü ile CMK m. 231/11'de düzenlenen "Denetim süresi içinde kasten yeni bir suç işlemesi veya denetimli serbestlik tedbirine ilişkin yükümlülüklere aykırı davranması halinde, mahkeme hükmü açıklar" normu, denetim süresi içinde sanığa ilk olarak, kasıtlı suç işlememe yükümlülüğü getirmektedir. ${ }^{113}$

Denetim süresi içinde işlenen taksirli suçlar hakkında yeniden HAGB kararı verilebileceği gibi, bu suç, önceki HAGB kararına tesir etmeyecektir. ${ }^{114}$ Fakat denetim süresi içinde kişinin kasten yeni bir suç işlemesi, keza denetimli serbestlik tedbirine ilişkin yükümlülüklere aykırı davranması halinde mahkeme hükmü açıklar (CMK m. 231/9). Burada yer alan "kasten bir suç işleme" tabiri nedeniyle, öncelikle yeni suçtan dolayı yürütülen muhakemenin

111 Özen'e göre, güvenlik tedbiri niteliğinde olan somut yükümlülüklerin hakimin takdirine bırakılması (CMK m. 231/8-c) kanunilik ilkesine aykırıdır, Özen, s. 1048. Türk Hukuk uygulamasında denetimli serbestlik tedbirine iş yükü gerekçesiyle çok sık başvurulmadığı, bu sebeple ÇKK'na benzer bir düzenlemeyle denetimli serbestlik müdürlüklerince takibe yasal olarak yer verilmesi ve tedbirin her durumda uygulanması gerektiği görüşünde Balo, s. 173.

112 Güngör/Okuyucu-Ergün, s. 1963; Dülger, s. 942; Özgenç, s. 722; Şahin/Göktürk, s. 203; Toroslu/Feyzioğlu, s. 66. Bu genel düzenlemeye karşın, TCK m. 191'de öngörülen denetimli serbestlik tedbiri hem zorunlu, hem de kapsam itibarıyla farklıdır.

113 Suçun yurtdışında işlenmesinin öngörülen şart bakımından aynı etkiye sahip olduğu belirtilmelidir, bkz. Fischer, §56f Rn. 3.

114 Öztürk, s. 646; Soyaslan, s. 447. 
tamamlanması, yani tesis edilen hükmün kesinleşmesi gerekir. ${ }^{115} \mathrm{Bu}$ hükmün, HAGB için öngörülen denetim süresinden sonra kesinleşmesi halinde nasıl bir yol izleneceği kanunda gösterilmemiştir. Bu aşamada, mevcut dosya ile ilgili muhakeme sonlandırılırken, sanık hakkında halihazırda kesinleşmiş bir hüküm yoksa hükmün ertelenebileceği ifade edilmektedir. ${ }^{116} \mathrm{Bu}$ görüş takip edilirse, önceki fiil sebebiyle devam olunan yargılama, sübjektif koşullar açısından da dikkate alınmamalıdır. Çünkü aksi tutum, "masumiyet" karinesiyle çelişir. ${ }^{117}$ Tartışılan husus CMK m. 231/10 hükmü ile birlikte yorumlandığında, en isabetli çözüm kanaatimizce şu şekilde olmalıdır: Denetim süresi geçmesine rağmen, kişi hakkında söz konusu süre içinde işlendiği iddia olunan suç sebebiyle devam eden bir muhakemenin varlığı halinde, mahkeme düşme kararı vermeyip yeni olaya ilişkin yargılamanın tamamlanmasını beklemelidir. ${ }^{118}$

CMK m. 231/9 ve diğer fikralarda, kişinin kasten yeni bir suç işleyip işlemediği belirleyicidir. Bakıldığında, söz konusu koşulda kişi hakkında mahkumiyet hükmü tesis edilmesine değinilmemiştir. $\mathrm{O}$ halde, TCK sistematiğinde benimsenen suçun yapısal unsurları dikkate alındığında ${ }^{119}$, kişinin haksızlık teşkil eden bir fiili ihlali yeterlidir. ${ }^{120} \mathrm{Bu}$ düzenleme kanaatimizce eksiktir ve sorunlu sonuçlara gebedir. Mesela kleptomani hastas1 olan A'nın, hastalığıyla alakalı olmayan bir fiil sebebiyle yargılandığını ve hakkında HAGB uygulandığını düşünelim. A, kendisi için öngörülen denetim süresi içinde başkasına ait taşınır malı zilyedinin rızası olmadan bulunduğu yerden almış olsun. Fail A, söz konusu eylemde TCK m. 141'de tanımlı suçu işlemiş, haksızlık teşkil eden eylemi gerçekleştirmiştir. Ancak kusur yokluğu sebebiyle (TCK m. 32/1) ceza almayacaktır. Ne var ki kast, haksızlığı meydana getiren tipik hareketin bir parçası olarak görüldüğünde, aslında fail bilerek

115 Bkz. Antalya BAM 1. CD, E. 2020/2925, K. 2021/944, 31.03.2021.

116 Öztürk, s. 646.

117 Karş. Öztürk, s. 646.

118 Artuç'a göre de, denetim süresi içinde işlendiği iddia olunan suçun yargılamasında Cumhuriyet savcisı ya da mahkeme, CMK m. 231/13 kapsamında bir araştırma yaparak HAGB kararı veren mahkemeyi bilgilendirmeli ve böylece mahkeme, düşme kararı için diğer suçtan yapılacak yargılamanın sonucunu beklemelidir, Artuç, s. 126; karş. Karakehya, s. 570. Ayıca bkz. "İkinci suçu denetim süresi içinde işlenmesi ve kasitll bir suç olması yeterlidir. İkinci suçun kesinleşme tarihinin önemi yoktur", Y. CGK, E. 2014/8-145, 2015/145, 05.05.2015. Alman Hukukunda emsal düzenlemede ( $556 \mathrm{f}$ StGB) belirleyici zaman suçun işlenme anıdır, Fischer, §56f Rn. 3.

119 Bkz. Koca/Üzülmez, s. 88.

120 Aksi görüşte Özen, s. 1050. 
ve isteyerek, yani kasten hareket etmiştir. Her ne kadar A, ikinci eyleminden ötürü ceza almasa da (CMK m. 223/3) kasitlı bir suç işlemiştir ve bu sebeple, fail hakkında daha önce verilen HAGB kararının kaldırılması gerekir. Varılan neticenin tutarsızlık doğurduğu söylenmelidir. Çünkü örnek olayda A hırsızlık suçu yerine taksirli bir suç sebebiyle cezalandırılsaydı, önceki HAGB kararına etkisi olmayacaktı. Failin sonraki suçta cezalandırılmasının HAGB'ye tesiri yokken, cezalandırılmadığı eylem dolayısıyla HAGB kararının kaldırılması ve hükmün açıklanması kendi içinde çelişkili görünmektedir. Bu nedenle kanaatimizce, TCK' da benimsenen suçun yapısal unsurlarıyla uyumlu olması bakımından "kasten yeni bir suç işleme" ifadesi "kasten işlediği bir suçtan mahkum olmadı̆ğ" şeklinde güncellenmelidir.

Denetim süresi içinde bilinçli taksirle işlenen suçun önceki HAGB kararı üzerinde etkisinin somut olay ve failin kişiliği tahliliyle farklı bir değerlendirmeye tabi tutulması gerekliliği de tartışılmaya değerdir. Çünkü bilinçli taksirde fail, neticeyi öngörmektedir. Halihazırda hakkında isnat olunan suç sabit görülmüş olan şahsın, denetim süresi içinde ayrı bir duyarlılıkla hareket etmesi zorunluluğu, HAGB'nin amaçları arasındadır. O halde bilinçli taksirle icra edilen eylemin, somut olayın şartları dikkate alınarak, HAGB'nin failden beklenen dikkat ve özene halel getirip getirmediği değerlendirilmeli, HAGB'nin varlığı ya da hükmün açıklanmasına bu cihette karar verilmelidir. Nitekim -§59 StGB atfıyla- §56f StGB’ye göre, deneme süresi içinde suç işlenerek cezanın ertelenmesinin temelinde yatan beklentinin yerinde olmadığ 1 gözlemlendiği takdirde hüküm açıklanacaktır. ${ }^{121}$ Benzer bir düzenlemenin -en azından- bilinçli taksirle işlenen fiiller için öngörülmesi isabetli olacaktır. $\mathrm{Bu}$ amaçla, CMK m. 231/10 veya m. 231/11'in sonuna olmak üzere, "Sanığın, denetim süresi içinde bilinçli taksirle işlediği bir suçtan mahkum olması halinde mahkeme, fiilin işlenişi ve saniğın durumunu değerlendirerek hükmü açıklayabilir" şeklinde bir cümle eklenmesi tarafımızca önerilmektedir.

\section{3. Öngörülen Tedbirlere Uygun Davranma Yükümlülüğü}

CMK m. 231/10'a göre, denetim süresi içinde kasten yeni bir suç işlenmediği ve denetimli serbestlik tedbirine ilişkin yükümlülüklere uygun davranıldığ1 takdirde, açıklanması geri bırakılan hüküm ortadan kaldırılarak, davanın düşmesi kararı verilir. CMK m. 231/11 uyarınca, sanığın denetim

121 Buradaki değerlendirmede tek başına suçun tür ve ağırlığı değil, sanığın başka suçlar işleyip işlemeyeceğine ilişkin mahkeme nezdinde uyanan kanaat belirleyicidir, Fischer, §56f Rn. 8 a. 
süresi içinde kasten yeni bir suç işlemesi veya denetimli serbestlik tedbirine ilişkin yükümlülüklere aykırı davranması halinde, mahkeme hükmü açıklar.

Kurulan hükmün sanık hakkında sonuç doğurmamasını ifade eden HAGB kararında, sanığa yüklenen tedbir yaptırım olarak değil, bir nevi adli kontrol tedbiri gibi görülmelidir. ${ }^{122}$

CMK m 231/8-c'de “... ya da takdir edilecek başka yükümlülüğ̈̈ yerine getirmesine" şeklindeki ifadeyle, denetimli serbestlik tedbirinin somutlaştırılması mahkemenin yetkisine bırakılmıştır. Mahkemenin tespit edeceği yükümlülüğün, sabit görülen suç ve açıklanması ertelenen ceza tür ve miktarıyla orantılı olmalıdır. ${ }^{123}$ HAGB kurumunda yetkili itiraz merci, olası bir kanun yolu müracaatında bu hususu da mutlaka değerlendirmelidir.

Kanundaöngörülendenetimeuygundavranılıpdavranılmadığıkonusunda, kanunda aç1klık olmasa da, 5402 sayılı Denetimli Serbestlik Hizmetleri Kanunu hükümleri gözetilerek, denetimli serbestlik müdürlüklerince takip yapılacağ1 belirtilmiştir. ${ }^{124}$ Suça sürüklenen çocuk hakkında uygulanacak denetimde ise, ÇKK m. 36 vd. dikkate alınmalıdır. ${ }^{125}$

Denetimli serbestlik tedbiri, denetim süresi boyunca değil, en fazla bir y1l süreyle getirilebilir (CMK m. 231/8). ${ }^{126}$ Suça sürüklenen çocuk hakkında öngörülen denetim için süre sınırı belirtilmemişse de (ÇKK m. 36), bu sürenin ÇKK m. 23'le uyumlu şekilde üç yıl ile sınırlı olduğu anlaşılmaktadır.

Tedbire aykırılık halinde HAGB kararının ortadan kaldırılacağı dikkate alındığında, denetim süresi için öngörülen beş yıl ile yükümlülük için belirlenen bir yıllık süre sınırı arasında uyumsuzluk göze çarpmaktadır. Sanık hakkında denetim süresinin zorunlu kılınmasının birincil amacı, bu süre zarfında cezanın somut yansımasından bağımsız olarak kişinin ıslahıdır.

\footnotetext{
122 Özbek/Doğan/Bacaksız, s. 714.

123 Genel ilkeye rağmen Alman Hukukunda §59a StGB hükmünde, yükümlülüklerin somut durum açısından orantılı olması koşuluna açıkça yer verilmiştir.

124 Olgun, s. 65.

125 ÇKK m. 37: "Denetim altına alınan çocukla ilgili olarak denetimli serbestlik ve yardım merkezi şube müdürlügü tarafindan bir denetim görevlisi görevlendirilir. Ancak, korunma ihtiyacı olan çocuklar veya suç tarihinde oniki yaşını bitirmemiş suça sürüklenen çocuklar ile çocuğun aileye teslimi yönünde karar verilmesi hâlinde, bu çocuklar hakkında denetim görevi gözetim esaslarina göre Sosyal Hizmetler ve Çocuk Esirgeme Kurumu tarafindan yerine getirilir".

126 Karş. TCK m. 191/3.
} 
Keza denetimli serbestlik yükümlülüğün gayesi de, cezai yaptırım yerine ilgili tedbirin işletilerek yine ceza ile ulaşılmak istenen ıslah amacını hayata geçirebilmektir. Denetimli serbestlik tedbiri için geçerli olan bir yıllık süre, kanunda ayrıca düzenleme olmadığından, HAGB kararının kesinleşmesiyle birlikte sonuç doğuracaktır. Azami hadden tedbir uygulandığı varsayılırsa, geriye kalan dört yıllık sürede yeni bir yükümlülüğe karar verilmesi mümkün değildir. Bir yıldan sonra, kalan dört yılın herhangi bir tedbir olmadan geçirilmesi, kişi hakkında bir tedbir getirilmiş olmasını da işlevsiz kılmaktadır. $\mathrm{Bu}$ nedenle kanaatimizce, ya denetim süresi daha kısa tutulmalı, ya da açıklanması ertelenen ceza miktarını aşmamak üzere, işlenen suçun niteliğine göre tedbirin uygulanma süresi daha uzun belirlenebilmelidir.

Denetimli serbestlik tedbiri açısından son olarak, denetim süresi ve mahkeme tarafından hükmedilen tedbirin başlangıç anı önem taşımaktadır. Kanunda buna ilişkin bir belirleme yapılmadığından, acaba HAGB kararına ilişkin hükmün tefhim ya da tebliği mi esas alınmalı, yoksa ilgili kararın kesinleşmesi mi beklenmelidir? CMK m. 269/1'de yer alan "Itiraz, kararın yerine getirilmesinin geri bırakılması sonисипи doğurmaz" düzenlemesi de dikkate alındığında, kararın açıklanmasının yeterli görüldüğü düşünülebilir. Fakat kanaatimizce, açıklanması ertelenen hüküm, esasında bir mahkumiyet hükmü ve karar (HAGB) mahkeme kararı niteliğini haiz olduğundan, bu kararın kesinleştiği tarih itibarıyla denetim süresi başlamalıdır.

Denetimli serbestlik yükümlülüğünün hukuki gereklilik ve yerindeliğine ilişkin, doktrinde Centel/Zafer tarafindan dile getirilen eleştiriyi bu bölümde paylaşmak gerekir. Yazarlara göre, CMK m. 231 kapsamındaki denetimli serbestlik hükmüyle kamu düzeninin korunması amaçlansa da ${ }^{127}$, aynı gaye takip edildiğinde sanığın belli haklardan yoksun bırakılabileceği ya da hakkında güvenlik tedbirlerinin uygulanabileceği iddia edilebilir ve bu iddia HAGB kurumunun hukuki niteliğiyle bağdaşmaz. Aynı şekilde, aslında hukuki sonuç doğurmayan bir kurum için, herhangi bir tazmin firsatı tanınmadan denetim serbestlik tedbirine ilişkin yükümlülükler getirilebilmesi hukuken isabetli değildir. Denetimli serbestlik tedbirine ilişkin yükümlülüklerin öngörüldüğü sistemde, anılan ihtimale binaen, oluşan zararın tazmin edilmesini mümkün kılan açık bir yasal düzenlemeye ihtiyaç duyulmaktadır. ${ }^{128}$ Kanaatimizce,

127 Ayrıca bkz. "Hükmün açıklanmasının geri bırakılması uygulaması için beş yıllık bir sürenin öngörülmesi ve bu sürede uygulanmak üzere denetimli serbestlik tedbiri olarak bir klsım yükümlülükler yüklenmesine olanak sağlanmast yasakoyucunun suç ve suçlulukla mücadele, caydırıcılık ve suç işlenmesinin önlenmesi amacıyla takdir yetkisine dayanarak kabul ettiği bir sistemdir", AYM, E. 2007/14, K. 2009/48, 12.03.2009 (RG: 25.06.2009, Say1: 27269).

128 Centel/Zafer, s. 878. Aynı endişe, Anayasa Mahkemesi'nin HAGB ile ilgili 2009 tarihli 
esasen suçu sabit görülmesine rağmen hakkındaki hükmün uygulanması askıya alınan kişinin, bu imkan karşısında belli yükümlülüklere katlanması doğaldır. Ancak yine de, doktrinde paylaşılan çekince ve öneriyi karşılamak için yasal bir düzenleme yapılması isabetli olacaktır. Bu noktada, Alman Hukukundaki emsal düzenleme örnek olabilir. Böylece, askıda bekleyen hükmün açıklanmasını gerektiren bir durum ortaya çıktığında, belli yükümlülükleri yerine getiren sanık hakkında, bu edimine karşılık cezadan mahsup imkanı tanınabilir (Bkz. §59 StGB atfiyla §56f/3). ${ }^{129}$

Nihayet, denetim süresi içindeki ihlal sebebiyle açıklanan hükmün kanun yolu denetiminde bozularak sanık lehine sonuçlanması halinde, yargılamanın makul sürede sonuçlanması gerekliliği yönüyle adil yargılanma hakkının da ihlal edileceği vurgulanmalıdır. ${ }^{130}$

\section{B. Nihai Hüküm Bakımından}

\section{Genel Olarak}

HAGB kararının verildiği dosya içeriğinde, suçun sanık tarafından işlendiği sabit görülmüş ve kişi hakkında hapis ya da adli para cezası

kararında yer alan karşı oy gerekçelerinde de paylaşı1mıştır: "231. maddeye eklenen dava konusu (12) numaralı fikrada, "Hükmün açıklanmasının geri bırakılması kararına itiraz edilebilir" denilmektedir. 5271 sayll Yasa'nın 267. ve devamındaki maddelerinde itiraz yolu düzenlenmektedir. Bu kanun yolunda, 288. maddede düzenlenen "temyiz" yolunda olduğu gibi bir hukuk kuralının uygulanmaması veya yanlış uygulanması nedenine dayalı inceleme yapılamayacağından "itiraz", diğer nedenlerle sinırl olarak incelenip kabul veya reddedilecektir. Ancak itirazın reddedilmesi ve daha sonra hükmün, açıklanmasını gerektiren koşulların oluşması halinde, bu hükme karşı temyiz yoluna başvurulması sonucu 289. maddedeki hukuka aykırllık hallerinin tespiti ile hükmün bozulmasina ve saniğın beraatine karar verilebilmesi olanaklıdır. Bu durumda, 231. maddenin (8) numaralı fikrası uyarınca, hükmün açıklanmasının geri bırakılması kararına bağlı olarak hakkında denetimli serbestlik tedbirlerinden birinin uygulanmasına karar verilmiş olan sanık, beraat edebileceği bir davada önceden temyize başvurma hakkı olmaması nedeniyle gereksiz bir yükümlülü̈k altında bırakılmış olacaktır. Bu tür temel hak ihlâllerine yol açılmaması için hükmün açıklanmasının geri bırakılması kararına bağlı olarak herhangi bir yükümlülük getirilmemesi veya bu kararlara karşı temyiz yolunun açılması gerekmektedir. Anayasa aykırıllğın hangi şekilde giderileceği ise kuşkusuz, yasakoyucunun takdirinde olan bir husustur", "Ceza sistemine yeni getirilen ve hükmün açıklanmasının geri bırakılmasına bağgl olarak uygulanan denetimli serbestlik kurumunun dayanağl olan mahkumiyet hükmünün esasının incelenmesine olanak vermeyen, "Hükmün açıklanmasının geri bırakılması kararına itiraz edilebilir" biçimindeki (12) numaralı fikranın Anayasa'nın 38. maddesinde öngörülen "Suçluluğu hükmen sabit oluncaya kadar, kimse suçlu sayılamaz" kuralına aykırıdır” AYM, E. 2009/222, K. 2009/55, 07.05 .2009 (RG: 07.10.2009, Say1: 27369).

129 Fischer, §56f Rn. 18.

130 Kaya, s. 421. 
belirlenmiştir. Ancak HAGB halinde ceza içeren hüküm askıda beklemekte ${ }^{131}$, şartlı mahkumiyet durumu ortaya çıkmaktadır. ${ }^{132}$ Doktrinde HAGB, CMK m. 223/8 ile karşılaştııılarak bir durma kararı olarak da yorumlanmaktadır. ${ }^{133}$ Başka bir görüşe göre HAGB, hüküm dişında kalan bir ara karar niteliğindedir. ${ }^{134}$ Yüksek Mahkeme'nin deyimiyle ise burada "koşullu bir düşme kararl" söz konusudur. ${ }^{135}$

Denetim süresi içinde dava zamanaşımının işlemeyeceğinin belirtilmesiyle de (CMK m 231/8-son cümle) ${ }^{136}$, HAGB halinde hükmün açıklanmadığı, başka deyişle davanın sona ermediği anlaşılmaktadır.

Hükmün sonuç doğurmaması nedeniyle, -TCK m. 54/4 hariç- bu aşamada müsadere hükümleri de uygulanamayacak ${ }^{137}$, hak yoksunluğundan bahsedilemeyecektir. ${ }^{138}$ Keza kişi, sanık sıfatını taşımaya devam edecektir. ${ }^{139}$

Hükmün açıklanmasının geri bırakılması kararı, bunlara mahsus bir sisteme kaydedilir. Bu kayıtlar, ancak bir soruşturma veya kovuşturmayla bağlantılı olarak Cumhuriyet savcısı, hakim veya mahkeme tarafindan

131 Şahin/Göktürk, s. 195; Toroslu/Feyzioğlu, s. 364.

132 Centel/Zafer, s. 876.

133 Akyıldız, s. 67; Balo, s. 172; Centel/Zafer, s. 873; Özbek/Doğan/Bacaksız, s. 714.

134 Karakehya, s. 562.

135 Y. CGK, E. 2009/4-13, K. 2009/12, 03.02.2009. Balo'ya göre, Yüksek Mahkeme'nin bu yorumu, kurumun niteliğiyle bağdaşmamaktadır. Çünkü düşme kararı, ancak denetim süresinin iyi halli geçirilmesi halinde verilir. Bu nedenle kurumu durma kararı ile kıyaslamak daha doğru olacaktır, Balo, s. 172.

136 Denetim süresi içinde kasten bir suç işlenmesi halinde zamanaşımının yeniden başlama anının nasıl tespit edileceğinin kanun metninden anlaşılamadığı ve sanık aleyhine yoruma açık olan CMK m. 231/8 hükmünün açıklı̆̆a kavuşturulması gerektiği görüşünde Özbek/ Doğan/Bacaksız, s. 716. Bu durumda zamanaşımının denetim süresi sonunda işlemeye başlayacağ1 yönünde Güngör/Okuyucu-Ergün, s. 1963.

137 Devrim Güngör/Haluk Toroslu, "Müsadere ve Hükmün Açıklanmasının Geri Bırakılması İlişkisi Üzerine Kısa Bir Değerlendirme”, 2016, 65(4), AÜHFD, s. 1977; Gökcen/Balc1/ Alşahin/Çakır, s. 631; Kartal, s. 73; Özbek/Doğan/Bacaksız, s. 715. §59/2 StGB hükmünde ise, müsadereye hükmedilebileceği, ancak güvenlik tedbiri uygulanamayacağı açıkça öngörülmüşsür.

138 Kumbasar, s. 195; Şahin/Göktürk, s. 201. Ancak mahkeme, açıklamayı geriye bıraktığ1 hükümde hak yoksunluğuna ilişkin kararını da vermelidir. Denetim süresi sonunda düşme kararı verildiğinde, hak yoksunluğu da sonuç doğurmayacaktır, bkz. Akkaş, s. 197.

139 Artuk/Gökcen/Alşahin/Çakır, s. 839; Centel/Zafer, s. 872; Dülger, s. 942; Kaya, s. 436; Kumbasar, s. 48; Özgenç, s. 714; Şahin/Göktürk, s. 201; Yıldırım, s. 438. Alman Hukukunda aynı yönde MüKoStGB/Groß/Kulhanek, § 59 Rn. 16. 
istenmesi halinde, bu maddede belirtilen amaç için kullanılabilir (CMK m. $231 / 13) .{ }^{140}$

HAGB kararının, -ilgili mevzuatta özel şart söz konusu olmadıkça- ${ }^{141}$ kişinin memuriyete girişinde engel oluşturmayacağı, keza tek başına memuriyetten çıkarmaya sebebiyet vermeyeceği ifade edilmektedir. ${ }^{142}$ Yine doktrinde, HAGB kararının mahkumiyet kararına konu maddi vaka ile sınırlı şekilde hukuk hakimini bağlayacağı savunulmaktadır. ${ }^{143}$

CMK m. 325/2 uyarınca, HAGB kararı verilmesi halinde tüm yargılama giderleri sanığa yüklenir. Yargıtay, HAGB kararının yargılama giderlerini kapsamadığı görüşündedir. ${ }^{144}$ Yüksek Mahkeme kararında, ilgili yorumun

140 “...5352 Sayll Kanun’un ‥ maddesine aykırı şekilde elde edilen bilgi ve belgelere dayalı olarak yapılan arşiv araştırması üzerine tesis edilen dava konusu işlemde hukuka uyarlık, İdare Mahkemesi'nin davanın reddine yönelik ısrar kararında ise hukuki isabet bulunmamaktadır" D. İDDK, E.2019/2425, K. 2020/715, 12.03.2020. Buna karșın, 17.04.2021 tarihinde yürürlüğe giren 7315 sayılı Güvenlik Soruşturması ve Arşiv Araştırması Kanunu m. 4/1-ç'ye göre, HAGB kararı arşiv araştırması kapsamına alınmıştır.

1417315 sayılı Güvenlik Soruşturması ve Arșiv Araştırması Kanunu m. 4/1-ç dikkate alındığında, istisnai durumun genişlediği söylenmelidir. Yine örnek olarak, 6.6.2015 tarihli Polis Meslek Eğitim Merkezleri Giriş Yönetmeliği m. 8'de, aday ve evliyse eşi hakkında belli suçlar hakkında verilen HAGB kararı, POMEM'lere başvuruda engeldir. Konuyla ilgili ayrıca bkz. D. 8. D., E. 2019/786, K.2019/8187, 03.10.2019. Yine Kamu Denetçiliği Kurumu Kanunu m. 10/1-f'de, belli suçlar yönünden HAGB kararı verilmiş olması, başdenetçi veya denetçi seçilebilmenin önünde engeldir. İlgili yasal düzenlemeyi paylaşan Akkaş'a göre; kanun koyucunun bu tercihi, HAGB kurumunun hukuki niteliği ile bağdaşmamaktadır, bkz. Akkaş, s. 197.

142 Güngör/Okuyucu-Ergün, s. 1955; Harun Kale, "Hükmün Açıklanmasının Geri Bırakılmasının Disiplin Cezalarına Etkisi”, 2011, 6(60), THD, s. 47. Doktrinde bu görüşü paylaşan Çınarlı/Arslan Hizal, Devlet Memurları Kanunu m. 48/A-5 hükmü üzerinden ek bir değerlendirme yapmaktadır. İlgili hüküm dikkate alındığında, HAGB kararına "af”tan, yani kanun koyucunun iradesinden daha öte bir anlam yüklendiği ve bu durumun HAGB kurumunun amacıyla bağdaşmadığı görülmektedir, bkz. Serkan Çınarlı/Sevinç Arslan Hızal, "Hükmün Açıklanmasının Geri Bırakılmasının Memuriyete Giriş ve Memuriyetin Sona Ermesine Etkisi”, 2017, 12(134), THD, s. 23 vd.

${ }^{143} \mathrm{Bu}$ konudaki görüş ve Yargıtay kararları çerçevesinde değerlendirmeler için bkz. Kadir Berk Kapanc1, "Ceza Mahkemesi Kararlarının Hukuk Mahkemesi Kararlarına Etkisi (TBK m. 74)", 2016, 7(1), İnÜHFD, s. 525; S1la Sencer/Ali Suphi Kurşun, "Hükmün Açıklanmasının Geri Bırakılmasının Hukuk Davalarına Etkisi”, 2017, 12(129), THD, s. 46.

144 "Her ne kadar önce verilen ve sonra bütünüyle kaldırllan bir cezanın varlı̆̆ nedeniyle tertip olunmuş ücreti vekalet ve yargllama gideri sorumluluğu söz konusu ise de bu tür tali yükümlülüklerin, yasa koyucunun amaçladı̆̆ düzeyde ceza olmadı̆̆ ve salt bu nedenle hükmün açıklanmasının ertelenmesinden yararlanılmak gerekmeyeceği kabul edilmelidir. Kaldı ki, 5271 sayılı CYY.nın 325. maddesinin 5560 sayılı Yasayla değişik 2. maddesi hükmü `hükmün açıklanmasının geri bırakılması hallerinde de yargılama giderlerinin sanıklara yükletileceğini öngörmekle, bu atıfetten yararlanmanın katılan sanıklar yararına bir sonuç 
sanık lehine olduğu da değerlendirilmektedir. Ne var ki bu durum, hem HAGB'nin hukuki sonuç doğurmamasi ${ }^{145}$, hem de denetim süresinin iyi halli geçirilmeyeceğinin peşinen kabul edilmesi yönüyle hukuken isabetsiz görünmektedir. ${ }^{146}$

\section{Düşme Kararı veya Hükmün Açıklanması}

HAGB kararı sonrasındaki süreçte mahkeme, duruma göre ya düşme kararı verecek, ya da hükmü açıklayacaktır.

CMK m. 231/10'a göre, denetim süresi içinde kasten yeni bir suç işlenmediği ve denetimli serbestlik tedbirine ilişkin yükümlülüklere uygun davranıldığı takdirde, duruşma açılarak HAGB kararı kaldırılır ve davanın düşmesine karar verilir. ${ }^{147}$

CMK m 231/11 uyarınca, sanığın denetim süresi içinde kasten yeni suç işlemesi veya denetimli serbestlik tedbirine ilişkin yükümlülüklere aykırı davranması halinde ${ }^{148}$ mahkeme, askıda bekleyen hükmü aynen açıklar. ${ }^{149}$

Mahkeme, kendisine yüklenen yükümlülükleri yerine getiremeyen sanığın durumunu değerlendirerek; cezanın yarısına kadar belirleyeceği bir kısmının infaz edilmemesine ya da koşullarının varlığı halinde hükümdeki hapis cezasının ertelenmesine veya seçenek yaptırımlara çevrilmesine karar

doğurmayacağını, aksine hükmün açılklanması ertelendiğinde 5 yıllık bir denetim süresine hükmedileceğinden daha aleyhe bir sonuç doğuracağını ortaya çıkarmaktadır...", Y. CGK, E. 2007/4-115, K. 2008/53, 18.3.2008. Aynı görüşte Aras, s. 84; Artuç, s. 120; Olgun, s. 67.

145 Hukuki sonuç doğuran ve istisnai nitelikte olan bu durumun yasal olarak CMK m. 231/5'te yer alması gerektiği görüşünde Caner Gürühan, "Hükmün Açıklanmasının Geri Bırakılmasına İlişkin Güncel Sorunların Yargıtay Kararları Işığında Değerlendirilmesi”, 2014, 26(111), TBBD, s. 145.

146 Ayrıca bkz. Taşdemir, s. 385. Yüksek Mahkemenin bu tutumunun masumiyet karinesine aykırı olduğu görüşünde Akyıldız, s. 80.

147 Temur, s. 153. Ayrıca bkz. Şen/Maviş, s. 59.

148 (§59 StGB atfiyla) §56f StGB’ye göre, denetim süresi içinde suç işlenerek cezanın ertelenmesinin temelinde yatan beklentinin yerinde olmadığı gözlemlenir ya da yükümlülüklere aykırılık söz konusu olursa, saklı tutulan hüküm açıklanacaktır, ayrıca bkz. Fischer, §56f Rn. 8a.

149 Y. 18. CD, E. 2015/24509, K 2017/6355, 23.05.2017. Ayrıca bkz. Akyıldız, s. 84; Gürühan, s. 150; Özbek/Doğan/Bacaksız, s. 710. Öyle ki mahkeme, açıklanmasını ertelediği kararda sonradan bir hukuka aykırılık tespit etse bile, hükmü aynen açıklamak durumundadır. Karardaki hukuka aykırılıklar, artık kanun yolunda çözümlenecektir, bkz. Güngör/OkuyucuErgün, s. 1964. Bu evrede esasen yeni bir hüküm kurulduğundan, önceki karara atıfla yetinilmemeli, karar mutlaka gerekçelendirilmelidir, bkz. Şahin/Göktürk, s. 205. 
verebilir. ${ }^{150}$ Denetimli serbestlik tedbirine aykırılık halinde suçun niteliğine dair bir değerlendirme yapmadan, sanığın sübjektif durumu dikkate alınarak cezanın infaz süresi kısaltılabileceği gibi, yasal şartları dahilinde erteleme veya seçenek yaptırımlara başvurulabilmektedir. ${ }^{151} \mathrm{Bu}$ ihtimalde, yine ceza tür ve miktarı değişmemekte, yalnızca hükmün infazı açısından farklı bir sonuç doğmaktadır. ${ }^{152}$

CMK m. 231/7'ye göre, “Açıklanmasının geri bırakılmasına karar verilen hükümde, mahkûm olunan hapis cezası ertelenemez ve klsa süreli olması halinde seçenek yaptırımlara çevrilemez". Bu düzenlemenin aksi düşünüldüğünde, HAGB kurumunun amacı ile çelişen bir durum ortaya çıkmaktadır. ${ }^{153}$ Fakat CMK m. 231/11'de, denetimli serbestlik tedbirine aykırılığın sonucunda mahkemeye, aynı dosyada erteleme ya da seçenek yaptırımlara çevirme imkanı verilmiştir. Bu hukuki yolun cezanın işlevselliği yönüyle tahlili gerekir. Seçenek yaptırımlara başvurulması halinde uygulamada asıl mahkûmiyet, çevrilen adli para cezası veya tedbirdir (TCK m. 50/5). Kendisine yüklenen denetimli serbestlik tedbirine uymayan kişi hakkında tesis edilecek nihai kararda, yine sanığın lehine olan bir başka kurumun (TCK m. 50/5) kullanılabilmesi isabetsiz olmuştur. Kanaatimizce, hakime bu yönde bir takdir yetkisi bırakılacaksa, CMK m. 231/11 açısından kısa süreli hapis cezasının seçenek yaptırımlara çevrilmesini-TCK m. 50/2'de yer alan istisnayı gözeterek- adli para cezası ile sınırlamak cezanın amaç ve işlevselliğine daha uygun düşecektir.

HAGB sonrası öngörülen denetim süresi içinde lehe kanun değişikliği söz konusu olursa, lehe durum mutlaka dikkate alınmalı; dosyada beraat verilmesini gerektiren bir değişiklik olursa da derhal beraat kararı verilmelidir. ${ }^{154}$ Aksi uygulamayla sanığın açıklanan hükmü istinaf veya temyize konu etmeye zorlanması, adil yargılanma hakkı ve usul ekonomisiyle çelişecektir.

150 Y. CGK, E. 2014/8-145, K. 2015/145, 05.05.2015.

151 HAGB açısından ayrı düzenleme içeren "Kullanmak için uyuşturucu veya uyarıcı madde satın almak, kabul etmek veya bulundurmak ya da uyuşturucu veya uyarıcı madde kullanmak" suçunda verilen hükmün ertelenmesi kararında ise, TCK m. 191/9 gereği hem CMK m. 231/10-11, hem de TCK m. 191/3 vd. birlikte dikkate alınacaktır. Fakat yorum yoluyla ulaşılan bu sonucun, TCK m. 191 ya da CMK m. 231'de açık şekilde düzenlenmesi isabetli olacaktır.

152 Özgenç, s. 722.

153 Dülger, s. 940; Özgenç, s. 718; Şahin/Göktürk, s. 200.

154 Özbek/Doğan/Bacaksız, s. 714. 


\section{HÜKMÜN AÇIKLANMASININ GERİ BIRAKILMASI KARARINA KARŞI KANUN YOLU}

Kanun koyucu, HAGB kararına karşı itiraz imkanı tanımıştır (CMK m. 231/12). HAGB kararında hükmün açıklanması ertelendiği ve böylece istinaf ya da temyize konu bir hüküm söz konusu olmadığından itiraz kanun yolunun tercih edildiğ $i^{155}$, yine HAGB'nin durma kararı mahiyetinde olduğundan bahisle itiraz kanun yolunun benimsenmesinin doğal olduğ ${ }^{156}$ doktrinde ifade edilmektedir.

Anayasa Mahkemesi, HAGB için itiraz kanun yolunun öngörülmesinde herhangi bir hukuki sorun tespit etmemiştir. ${ }^{157}$ Anılan kararda paylaşılan yorumla uyumlu olarak, CMK m. 231/10'a göre verilen düşme kararına ve sanığın denetim süresi içinde kasten bir suç işlemesi ya da öngörülen denetimli serbestlik tedbirine aykırı davranması sonucu mahkeme tarafından açıklanan hükme karşı istinaf ve temyiz kanun yolu açıktır. ${ }^{158}$

\section{A. Yetkili Merci}

Hakim kararları ile kanunun gösterdiği hallerde mahkeme kararlarına karşı itiraz yoluna gidilebilir (CMK m. 267). HAGB kararına karşı itiraz kanun yolu öngörüldüğüne göre, sürecin tabi olduğu usul ve esaslar hakkında CMK m. 268 vd. maddeleri belirleyicidir.

CMK m. 268/1'de itiraz usulü düzenlendikten sonra, m. 268/2'de, kararına itiraz edilen hakim veya mahkemenin, itirazı yerinde görürse kararını düzelteceği; yerinde görmezse en çok üç gün içinde itirazı incelemeye yetkili olan mercie göndereceği hüküm altına alınmış, yetkili merci ise CMK m

155 Şahin/Göktürk, s. 201; Rezzan İtişgen, “Ceza Muhakemesi Hukukunda İstinaf”, 2014, 5(16), TAAD, s. 380; Yıldırım, s. 444; Yalçın, s. 228.

156 Centel/Zafer, s. 874; Karakehya, s. 572.

157 “(12) numaralı fikrada hükmün açıklanmasının geri bırakılması kararına itiraz edilebileceğ $i$ belirtilmekte ise de, bu kuralla temyiz incelemesi yolu kapatılmış değildir. İtiraz yolu, verilen kararın bir üst merci tarafindan yeniden gözden geçirilmesini sağlayan ve kararın sağglığı bakımından güvence oluşturan kanun yollarından biridir. Hükmün açıklanmasının geri bırakılması kararları sanık hakkında hukuki sonuç doğuran kesin hüküm niteliğinde olmadı̆̆ından, deneme süresi sonunda verilecek düşme kararı veya geri bırakma koşullarına uyulmaması halinde verilecek karar hakkında esas hükümle birlikte temyiz denetimi olanaklı bulunmaktadır" AYM, E. 2009/222, K. 2009/55, 07.05.2009 (RG: 07.10.2009, Say1: 27369).

158 Güngör/Okuyucu-Ergün, s. 1963; Toroslu/Feyzioğlu, s. 368. Olağan kanun yolunun açık olduğu yönünde bkz. Y. CGK, E. 2009/4-13, K. 2009/12, 03.02.2009. Düşme kararı yönünden karş. İtişgen, s. 380. 
268/3'te tanımlanmıştır. ${ }^{159}$

İtiraz konusunda, bölge adliye mahkemelerinin rolü de ele alınmalıdır. CMK m. 280/2'de 'Duruşma sonunda bölge adliye mahkemesi istinaf başvurusunu esastan reddeder veya ilk derece mahkemesi hükmünü kaldırarak yeniden hüküm kurar" şeklindeki düzenleme, bölge adliye mahkemelerince HAGB kararı verilebilmesini sorgulamayı gerektirir. ${ }^{160}$ Çünkü "hüküm” tabiri hukuken CMK m. 223'te karşılık bulmaktadır. Oysa HAGB, bünyesinde mahkumiyet barındırsa da, teknik olarak hüküm çeşidi değildir. ${ }^{161}$ Şayet HAGB, CMK m. 223'ün bir parçası sayılırsa, bu durumda HAGB kurumu ile hapis cezasının ertelenmesi (TCK m. 51) arasında niteliksel bir fark kalmayacak ve bu tutum, hükmün sonuç doğurmamasına bağlanan neticeleri etkileyecektir. Yine HAGB, CMK m. 223'ün bir parçası ise, istinaf ya da temyiz yerine itiraz kanun yolunun mümkün görülmesi de tutarsılılk oluşturacaktır. Ancak uygulamada, ilk derece mahkemesi tarafindan verilen hükme karşı istinaf kanun yoluna başvurulması ve bölge adliye mahkemesinin CMK m. 280/1-g ve 2 kapsamında yeniden duruşma yapması halinde HAGB kararı verilmektedir. ${ }^{162}$ Böylece bölge adliye mahkemesince verilen HAGB kararına karşı itiraz da mümkündür (CMK m. 268/3-e). ${ }^{163}$

\section{B. Yetki Sınırları}

İtiraz kanun yoluna başvurulması halinde yetkili merciin ne yönde işlem tesis edeceği noktasında CMK m. 271 yol göstericidir. İlgili maddeye göre, kanunda yazılı olan haller saklı kalmak üzere, itiraz hakkında duruşma yapılmaksızın karar verilir (CMK m. 271/1) ve itiraz yerinde görülürse merci, aynı zamanda itiraz konusu hakkında da karar verir (CMK m. 271/2). ${ }^{164}$

HAGB kapsamında aslında iki karar verilmiş görünmektedir. İlki, iki y1l veya daha az süreli hapis veya adli para cezası, yani suçun işlendiğinin sabit olmasıdır. İkinci husus ise, işlendiği sabit görünen suça ilişkin tespit

\footnotetext{
159 Soyaslan, s. 445.

160 Nitekim CMK m. 223'e göre hüküm kurulacağ1 yönünde İtişgen, s. 400. HAGB kararı verilmesinin hukuken mümkün olduğu görüşünde Öztürk, s. 731; Ayrıca bkz. Fatih Birtek, Ceza Muhakemesinde İstinaf, Adalet Yayınevi, 2019, s. 306.

161 Baştürk, s. 67.

162 Uygulamadan örnek olarak bkz. Antalya BAM 1. CD, E. 2017/2731, K. 2018/345, 07.02.2018; Gaziantep BAM 15. CD, E. 2017/1978, K. 2018/735, 12.04.2018.

163 Öztürk, s. 732.

164 Faruk Turhan, Ceza Muhakemesi Hukuku, 1. Bask1, Asil Yayınevi, 2006, s. 405.
} 
edilen ceza tür ve miktarıdır. ${ }^{165} \mathrm{O}$ halde şu soru hukuken tatmin edici şekilde cevaplanmalıdır: HAGB'nin itiraz konusu edilmesi halinde, sadece HAGB'nin yasal şartları mı tahlil edilecektir, yoksa yerel mahkemenin dava konusu olaya ilişkin hukuki değerlendirmeleri de gözden geçirilecek midir? ${ }^{166}$

Doktrinde, HAGB kararına konu olay üzerinde itiraz merci tarafından hukuki değerlendirme yapılması halinde, kanun yolunun istinafa dönüşeceği görüşü paylaşılmıştır. ${ }^{167}$ Gerçekten, itiraz merciinin aynı zamanda itiraz konusu hakkında da karar verebileceğine ilişkin hüküm (CMK m. 271/2) değerlendirildiğinde ${ }^{168}$, dava konusu olayın farklı mütalaa edilmesi ihtimalinde HAGB kararı kaldırılmakla kalmayıp, yine merci tarafindan yeni bir hüküm tesis edilecektir. Fakat ele alınan ve yeniden değerlendirilen karar, mahkumiyet barındıran bir mahkeme kararıdır. O halde, mahkeme kararının esastan incelenmesi isteniyorsa, kanaatimizce de ilgili kanun yolu istinaf olmalıdır. ${ }^{169}$ Çünkü ertelenen hükmün kendisi, esasen mahkemenin takdir ettiği bir mahkumiyet hükmüdür. Ancak mevcut düzenlemedeki bu tutarsızlık, HAGB'nin objektif koşullarla sınırlı incelenmesi sonucunu doğurmamalıdır. ${ }^{170}$

165 Olgun Değirmenci, "Yargı Kararları Çerçevesinde HAGB Kararının Hukuki Denetimi ve İtirazın Kapsamı”, 2019, 1(2), Erciyes Üniversitesi Hukuk Fakültesi Sempozyum Dergisi, s. 81. Ayrica bkz. MüKoStGB/Groß/Kulhanek, § 59 Rn. 15.

166 CMK'da yer alan itiraz kurumu öngörüldüğünde henüz HAGB'nin yasal olarak düzenlenmemiş olması ve HAGB'nin nihayetinde hüküm üzerinden verilmesinden dolayı, itiraz denetimine ilişkin duraksamaların yaşanması doğaldır, bkz. Değirmenci, "İtirazın Sinırları", s. 82.

167 Centel/Zafer, s. 883; Güngör/Okuyucu-Ergün, s. 1961; Yenisey/Nuhoğlu, s. 801; Yıldırım, s. 453 .

168 Turhan, Ceza Muhakemesi, s. 405.

169 Şahin/Göktürk'e göre, itiraz kurumu, diğer olağan kanun yolları istinaf ve temyiz gibi, karar ve hükümlerin denetlenmesi için getirilmiştir. Bu yönüyle HAGB kararına itiraz halinde de suçun vasfı ve sübutuna ilişkin değerlendirme yapılmalıdır. HAGB halinde bir hüküm söz konusu olmadığı için itiraz kanun yolu benimsenmiştir, Şahin/Göktürk, s. 201. HAGB kararına karşı istinaf ya da temyiz kanun yolu yerine itirazın mümkün görülmesiyle birlikte, sanık lehine getirilen bir düzenlemenin sanık aleyhine kullanıldığı görüşünde, Ünver/ Hakeri, s. 686. Yıldırım'a göre, HAGB kararına karşı itiraz halinde yapılan geniş hukuki değerlendirme, kararın denetlenmesi yönünden olumlu, ancak hakimin takdir yetkisine müdahale boyutuna varması sebebiyle olumsuz görünmektedir. HAGB kurumunda itiraz yerine istinaf kanun yolunun benimsenmesi, sanık ve uygulama yönünden daha isabetli olacaktır, Yıldırım, s. 455; benzer görüşte Ali Tanju Sarı̈ül, "Hükmün Açıklanmasının Geri Bırakılması Kararlarının Denetiminde Kanun Yolu Sorunu", 2016, 29(125), TBBD, s. 83; Gürühan, s. 158. Yalçın'a göre de, HAGB'nin hukuki niteliği gereği istinaf mümkün olmamakla birlikte, HAGB kararının kanun yolu bakımından hüküm sayılmasına dair CMK m. 231/11'e ekleme yapılmalıdır, Yalçın, s. 279.

170 "İtiraz yerinde görülürse merci, aynı zamanda itiraz konusu hakkında da karar verir 
Çünkü "itiraz konusu" olan HAGB kararı aslında sabit görünen suç fiiline dayandığına göre, suçun sübut ve vasfina ilişkin değerlendirme hukuken kaçınılmazdır ve öngörülen (itiraz) kanun yolunun parçasıdır. Sonuç olarak, CMK m. 231/12 kapsamında yapılan itiraz üzerine yetkili merci HAGB kararının koşullarına ilişkin değerlendirme yapacak, bu aşamada hükme konu suçun sübut ve vasfını da dikkate alacaktır. ${ }^{171}$ Öyle ki, suçun sübutuna etki etmesi nedeniyle delillerin hukuka uygunluğu da değerlendirilecektir. ${ }^{172}$ Yargıtay'ın son dönem içtihadı da, HAGB kararına itiraz halinde şekli ve maddi yönden inceleme yapılacağı yönündedir. ${ }^{173}$

Önemle belirtelim ki, sadece HAGB'nin yasal şartlarıla sınırlı bir inceleme halinde sanık hakkında verilen mahkumiyet kararının denetlenememesi sebebiyle adil yargılanma hakkı ile hak arama özgürlüğünün gerektirdiği etkin başvuru yolu sınırlanacak ve sanık adeta HAGB'yi reddedip diğer kanun yollarına başvurmaya zorlanacaktır. ${ }^{174}$ Ayrıca mahkeme kararına karşı elverişli bir denetim mekanizmasının yokluğu, sadece sanık yönünden değil, mağdur/suçtan zarar gören açısından da hak arama özgürlüğünü kısıtlayacaktır. ${ }^{175}$ Sonuç itibarıyla, Yargıtay'ın güncel içtihadının AİHS m. 13 ve Ek 7 No'lu Protokolü ile uyumlu olduğu söylenmelidir. ${ }^{176}$

(CMK m. 271/2)" hükmüyle, yetkili merciin yalnızca HAGB kararının şartları üzerinden şekli bir denetim yapabileceği, görüşünde Güngör/Okuyucu-Ergün, s. 1961. Bir başka görüşe göre itiraz merci, HAGB kararını sadece maddi koşulların varlığı yönünden denetler. Suçun vasfı ve ceza miktarı gibi bu kapsamın dışına çıkan hususlar temyiz kapsamında değerlendirilmelidir, Meran, s. 70.

171 Artuk/Gökcen/Alşahin/Çakır, s. 845; Değirmenci, “İtirazın Sınırları”, s. 99; Dülger, s. 941; Şahin/Göktürk, s. 201; Özbek/Doğan/Bacaksız, s. 712; Veli Özer Özbek/Serkan Merakl1, "Karar İncelemesi: Hükmün Açıklanmasının Geri Bırakılması Kararına İtiraz Üzerine Yapılacak Denetim”, 2013, 19(2), MÜHF-HAD, (Prof. Dr. Nur Centel'e Armağan), s. 228; Yenisey/Nuhoğlu, s. 803.

172 Şahin, s. 290.

173 Y. CGK, E. 2012/10-534, K. 2013/15, 22.01.2013. Buna karşın Yargıtay'ın önceki tutumu “...itiraz merciin yetisi, 5271 sayll CYY'nin 231/6. maddesinde üç bent halinde siralanan uygulama koșullarının varlığını denetlemekle sınırlıdır..." șeklindeydi, Y. 4. CD, 11.02.2009, E. 2008/19326, K. 2009/2363. Yargının güncel tutumu nedeniyle, HAGB kararına itirazın şartlarına ilişkin kanunda özel bir düzenleme yapılmasına ihtiyaç kalmadığı, görüşünde Şahin, s. $290 \mathrm{vd}$.

174 Değirmenci, “İtirazın Sınırları”, s. 93; Özbek/Meraklı, s 230; Yıldırım, s. 453. Bu durumun masumiyet karinesiyle de bağdaşmayacağı görüşünde Ünal, s. 211.

175 Özbek/Başbüyük, s. 9 vd.

176 Kaya, s. 420; Yıldırım, s. 456. Ayrıca bkz. Özbek/Merakl1, s 233. 
HAGB için öngörülen sübjektif koşullar ${ }^{177}$ ile iddianamedeki eksiklikler ve vekalet ücreti gibi konular, itiraz incelemesinin dışındadır. ${ }^{178}$ Diğer yandan, HAGB kararının içeriğini oluşturan ve hakimin takdirine bırakılan denetimli serbestlik tedbirinin hukuken ölçülü olmadığ değerlendirilebilir. ${ }^{179}$

HAGB kararının hukuki olmadığ kanaatine ulaşan itiraz merci yeni bir hüküm vermeyecek, sadece HAGB kararını kaldırarak dosyayı esas mahkemeye geri gönderecektir. ${ }^{180}$ Yargıtay'a göre de itiraz merci, görevsizlik, düşme ya da ceza verilmesine yer olmadığı kararı ile sınırlı kalarak hükmü değiştirebilecek, fakat bunun haricindeki hallerde esas mahkemenin yerine geçerek yeni bir hüküm tesis edemeyecektir. ${ }^{181}$

İtiraz kanun yolunda HAGB'nin kaldırılarak dosyanın esas mahkemeye gönderilmesi halinde karara karşı direnme hakkı yoktur. ${ }^{182}$ Doktrinde, itirazın kabulü halinde, gerekçe olarak suç vasfinın farklı değerlendirilmesine dayandırılsa da, esas mahkemenin görev yönünden yetkisizlik kararı dahil yeni bir hüküm tesis edemeyeceği, açıklanması ertelenen hükmü açıklamakla yetineceği savunulmaktadır. ${ }^{183}$ Kanaatimizce, itiraz mercii HAGB kararını maddi bakımından inceleyebiliyorsa, itirazın kabulünden sonra esas

177 Kumbasar, s. 225; Özbek/Merakl1, s. 228.

178 Şahin, s. 290.

179 Toroslu/Feyzioğlu, s. 368.

180 Akyıldız, s. 83; Artuç, s. 124; Dursun, s. 168; Meran, s. 70; Yıldırım, s. 456. Karş. Centel/ Zafer, s. 884. Doktrinde Özbek/Merakll'ya göre, itiraz merciin yeni bir karar verilmesi için dosyayı ilk derece mahkemesine göndermesi şeklinde bir yetki, yasada açıkça tanımlanmamıştır. O halde, HAGB kararına itiraz halinde yetkili merci, itirazı haklı bulduğu takdirde, -muhakeme eksiklikleri dahil-gerekli hükmü tesis etmek durumundadır. Özbek/ Meraklı, s. 232. Öztürk'e göre ise, sanığın beraat etmesi gerekiyorsa, itiraz merci beraat karar1 vermelidir, Öztürk, s. 652 vd.

181 “...Hükmün Açıklanmasının Geri Bırakılması Kararına itiraz halinde, mercii CMK’nın 231. maddesinin 6. fikrasında yer alan suça ve sanığa ilişkin objektif uygulama koşullarının var olup olmadiğ ve hem maddi hem de hukuki anlamda işin esasına girmek suretiyle aykırılık görmesi halinde sadece gerekçesini göstermek suretiyle kararı bozup başkaca bir işlem yapmaksızın mahkemesine gönderecek; yeniden dosyayı ele alan hâkim bozma gerekçesi ile sinırlı kalarak Ceza Genel Kurulu'nun 22.01.2013 tarih, 2012/10-534 esas ve 2013/15 sayll kararı doğrultusunda görevsizlik, düşme ya da ceza verilmesine yer olmadığına şeklinde karar vermek suretiyle sinırlı olarak hükmü değiștirebilecektir" Y. 13. CD, E. 2014/32524, K. 2014/37202, 29.12.2014.

182 Artuç, s. 124; Yıldırım, s. 457.

183 Şahin, s. 294. 
mahkeme de yeni bir hüküm kurabilmelidir. ${ }^{184}$ Hatta itiraz üzerine verilen kararlara karşı direnme yasağ1 söz konusu olduğundan, suç vasfina ilişkin farklı değerlendirmeler halinde, esas mahkemenin buna uyması ve yeni bir hüküm tesis etmesi zorunludur. Ayrıca mahkemenin, önceki karardan farklı gerekçelere dayanmak kaydıyla yeniden HAGB uygulaması mümkün görülmelidir. ${ }^{185}$

HAGB kararına yalnızca sanık tarafindan itiraz edilmesi ve HAGB kararının kaldırılması sonrasında, sanık hakkında verilecek cezada, açıklanması ertelenen ceza miktarının geçilemeyeceği belirtilmekte ve bu görüş "aleyhe bozma yasağı" na dayandırılmaktadır. ${ }^{186}$ Kanaatimizce, aleyhe bozma yasağının CMK m. 231/11 kapsamında geçerli olabilmesi, ancak açık yasal düzenleme halinde mümkündür. ${ }^{187}$

184 Aynı yönde Şen/Maviş, s. 50.

185 Aynı yönde Yıldırım, s. 458; karş. Karakehya, s. 574. Buna karşın Yargıtay'ın tutumu, hükmün açıklanması yönündedir: “...Sanık ... hakkındaki hükmün açıklanmasının geri bırakılmasına ilişkin hükümlerin itiraz sonucu mercii tarafindan kaldırılmasını müteakip mahkemece duruşma açılarak, sanığın duruşmaya çağrılması, varsa diyecekleri ve son sözü sorularak yapılan yargılama sonucuna göre aynı Kanunun 230. maddesi uyarınca hüküm fikrasında bulunması gereken bütün hususlar da gözetilerek yeniden hüküm kurulması ve bu hükmün açıklanması gerektiği gözetilmeden, savunma hakkını kısıtlayacak biçimde sanık duruşmaya davet edilmeksizin ek karar verilmesi..."Y. 18. CD, E. 2010/8615, K.2012/898, 18.01.2012.

186 Özbek/Doğan/Bacaksız, s. 712. “...klyas metodunun ceza hukukunun aksine ceza muhakemesi hukukunda kural olarak serbest olduğu ve ceza muhakemesi hukukunda genişletici yorum yapılabileceği gözetildiğinde aleyhe bozma yasağının düzenlediği 5320 sayılı Kanunun 8. Maddesi uyarınca halen yürürlükte bulunan 1412 sayılı CMUK'nın 326/son maddesinin, itiraz kanun yolunda uygulanmast mümkün olduğundan, somut olayda hükmün açıklanmasının geri bırakılması kararı aleyhine yalnızca sanık tarafindan itiraz kanun yoluna başvurulduğu, bu sebeple aleyhe değiştirme (bozma) yasağ gereğ ilk verilen ceza miktarından daha fazla cezaya karar verilemeyeceği gözetilmeden yazılı sekilde karar verilmesi...”, Y. 4. CD, E. 2017/7422, K. 2018/7718, 24.12.2018. Buna karşın önceki tarihli kararında Yargıtay, itiraz kanun yolunda aleyhe bozma yasağının uygulanamayacağ 1 görüşünü paylaşmıștır, "Ceza mahkemeleri tarafindan verilen "hükmün açılanmasının geri bırakılmasına” dair kararın, 5271 Sayılı CMK'nın 223/1. maddesinde öngörülen davayı esastan sonlandırıcı, hüküm niteliğinde olmadiğl ve bu suretle temyizinin mümkün bulunmadĭ̆ıl, ancak itiraz yolunun açık bulunduğu, 1412 Sayılı CMUK'un 326/ son, 5271 Sayll CMK'nin 283 ve 307/4. maddelerinde düzenlenen aleyhe bozma veya aleyhe değiștirme yasă̆ının sadece davanın esasını çözümleyen hükümlerle sinırlı olarak istinaf veya temyiz yasa yolunda kabul edilmesi sebebiyle aleyhe bozma yasağının ve ceza bakımından kazanılmış hak ilkesinden itiraz mercii tarafindan verilen kararlar açısından söz edilemeyeceği anlaşılmakla tebliğnamedeki görüşe iştirak edilmemiş olup...”, Y. 12. CD, E. 2013/27999, K. 2015/9190, 28.05.2015.

187 Yıldırım, s. 442. Karş. Centel/Zafer, s. 884. Doktrinde Ersoy'a göre, CMK'da açık bir düzenleme olmamasından dolayı, HAGB kararına itiraz halinde, yorum ya da kıyas yoluyla 
Esas mahkemesi tarafından verilen karar artık yeni bir hükümdür ve genel kurallara göre kanun yoluna tabidir. ${ }^{188}$ İstinaf ya da temyize başvurulmadan kesinleşen karar ya da hükme karşı kanun yararına bozma işletilebildiğinden, kesinleşen HAGB kararına karşı da kanun yararına bozmaya başvurulabilir. ${ }^{189}$ Diğer yandan, HAGB kararına karşı yargılamanın yenilenmesi yolu açık tutulmamıştır. ${ }^{190}$

\section{Sanığın İtiraz Hakkı Üzerine Bir Değerlendirme}

CMK m 268/1'de, ilgililerin kararı öğrendiği günden itibaren yedi gün içinde itiraz edebileceği düzenlenmiştir. Bu hüküm doğrultunda muhakeme süjeleri kanun yoluna başvurabilir. Ancak HAGB'nin tabi olduğu koşullardan birinin sanığın kabulü olduğu düşünüldüğünde, bu bapta sanığın itiraz hakk1 ayrıca irdelenmelidir. ${ }^{191}$

Kanun yolu safhası, maddi gerçeğe ulaşma çabasıyla şekillenen ceza muhakemesinde, yargılamada oluşan kanaatin hukuka uygun ve adil

dahi aleyhe değiştirme yasağının uygulanması mümkün değildir. Ancak bu halde; kanun yoluna başvuracak sanığın, daha ağır bir ceza ile karşılaşma endişesi yaşayacağı açıktır. Dolayısıla mevcut durum, adil yargılanma hakkını ihlal etmektedir. Bu kanaat ve tespiti paylaşan yazar, CMK m 231/11'de yasal bir değișiklik yapılmasını ve aleyhe bozma yasağının HAGB kararına itiraz halinde de geçerli olmasını önermektedir, Uğur Ersoy, Ceza Muhakemesi Hukukunda Aleyhe Değiştirme (reformatio in peius) Yasağı, Adalet Yayınevi, 2018, s. 390 vd. Doktrinde Kaymaz, CMK m. 265 hükmünün kıyasen uygulanarak itiraz kanun yolunda da geçerli olması ve bu şekilde HAGB kararına itiraz halinde de aleyhe değiştirme yasağının işletilebileceği kanaatindedir, Seydi Kaymaz, "Aleyhe Değiştirme Yasağı”, 2013, 19(2), MÜHF-HAD, (Prof. Dr. Nur Centel’e Armağan), s. 1416.

188 Şahin, s. 293.

189 Y. CGK, E. 2014/15-487, K. 2018/151, 10.04.2018. Ayrıca bkz. Güngör/Okuyucu-Ergün, s. 1962; Özbek/Doğan/Bacaksız, s. 713; Ünver/Hakeri, s. 685. Kanun yararına bozma halinde, karar sadece şekli açıdan incelenmektedir, Özbek/Başbüyük, s. 11.

190 "CMK'nın 311 ve devamı maddelerinde düzenlenen yargılamanın yenilenmesi, ancak kesin hükümlere karşı başvurulabilecek olağanüstü bir yasa yolu olup, hüküm niteliğinde bulunmayan hükmün açıklanmasının geri bırakılması kararına karşı yargılamanın yenilenmesi isteminin, CMK'nın 318/1. maddesi uyarınca kabule değer olmaması nedeniyle reddine karar verilmesi gerekirken, anılan madde uyarınca istemin kabulüne karar verilip, yargılama yapılarak yazılı şekilde karar verilmesi, bozmayı gerektirmiștir", Y. 2. CD, E. 2012/4860, K. 2012/3949, 22.02.2012. Aynı yönde Güçlü Akyürek, Yargılamanın Yenilenmesi, 3. Bask1, Seçkin Yayınevi, 2018, s. 54. Bu kanun yolunun, "yargılama" kavramının geniş yorumu ve lekelenmeme hakkına dayanarak mevcut yasal koşullarda içinde mümkün görülmesi gerektiği yönünde Şen/Maviş, s. 58.

191 Nitekim doktrinde Özen'e göre, müdafi huzurunda bilgilendirilen sanığın itiraz hakk1 yoktur, Özen, s. 1057. 
olabilmesinin teminatıdır. ${ }^{192} \mathrm{Bu}$ haktan ilk yararlanacak süje, masumiyet karinesiyle korunan sanıktır. ${ }^{193}$ Kanun yoluna başvuran sanığın, bu yetkiyi ancak kendi lehine kullanabileceği ifade edilmektedir. ${ }^{194} \mathrm{O}$ halde HAGB kararına itiraz eden sanık, yalnızca daha lehe bir kurumun uygulanması gerekçesiyle bu yola başvurabilir. Fakat burada tartışmalı olan husus, HAGB'yi kabul eden sanığın, kabul ettiği kararın kaldırılmasını talep etmesidir. Aslında olması gereken, kararın hukuka aykırı olduğunu düşünen sanığın, HAGB'yi kabul etmeyip, hükme karşı istinaf ya da temyize başvurmasıdır. Ne var ki, yukarıda değindiğimiz üzere- sanıktan HAGB kararına dair hukuki sonuçları tahlil edebilmesini beklemek mümkün olmadığ gibi, muhakeme sürecinde HAGB'nin kabulü noktasında bir kanaatin oluşması da doğaldır. Diğer yandan, HAGB tatbikinin kabulünün itiraz hakkını ortadan kaldıracağı savunulursa; karar, diğer ilgililer başvurmadıkça kanun yolu denetiminde geçmeden kesinleşecektir. Kanunda açık bir istisnaya yer verilmemişken bu tutumun benimsenmesi hukuka aykırı olacağı gibi, sanık lehine görünen HAGB'yi son tahlilde aleyhe bir kuruma dönüştürecektir. Tüm bu değerlendirmelerle, sanığın HAGB'ye karşı kanun yoluna başvuru hakkı istisnasız şekilde kabul edilmelidir.

\section{GENEL DEĞERLENDİRME VE HUKUKİ ÖNERILLERIMIZ}

HAGB kurumu hakkında tespit ettiğimiz temel sorunlara ilişkin genel değerlendirme ve hukuki önerilerimiz, şu şekilde özetlenebilir:

1- HAGB'nin objektif şartlarından biri olarak sonuç ceza sınırı esas alınmış, katalog suç düzenlemesi tercih edilmemiştir. AİHM ve Anayasa Mahkemesi içtihatlarında ise, temel olarak insan haysiyeti ile bağdaşmayan muamele yasağına dayanılarak, bazı suçlar hakkında HAGB uygulanması AİHS ve Anayasa'ya aykırı görülmektedir. Bu istisna dairesinin içtihada terk edilmesi yerine, HAGB uygulanabilecek suçların yasada açıç̧a düzenlenerek, sorunlu görülen suçların kapsam dışı bırakılması daha isabetli olacaktır. Çünkü içtihatlarda dayanılan çekince, kişilere karşı suçların birçoğunda ileri sürülebilir.

2- CMK m. 231/6-a'da yer alan "Saniğın daha önce kasitlı bir suçtan mahkûm olmamış bulunması" şartında "daha önce" ibaresi, HAGB'ye

192 Karakehya, s. 602; Ali Şahin Kılıç, "Ceza Muhakemesinde İstinaf Kanun Yoluna Teorik Bir Bakış”, 2019, 1(2), Erciyes Üniversitesi Hukuk Fakültesi Sempozyum Dergisi, s. 112.

193 Kılıç, s. 113.

194 Karakehya, s. 608. 
konu suçtan önceki tarihte işlenen fiile ilişkin mahkumiyet hükmü, şeklinde anlaşılmalıdır. Bu yorum, cezanın işlevselliği doğrultusunda desteklenmelidir. Ancak hükümdeki ifade farklı yorumlara açık kapı bıraktı̆̆ından, CMK m. 231/6-a'da yer alan şart "daha önceki tarihli ve kasten işlenmiş bir suçtan mahkum olmamak" şeklinde güncellenip açık ve anlaşılır kılınmalıdır. Diğer yandan, yorum farkından bağımsız olarak, önceki suçun çocuk tarafından işlenmesine farklı bir sonuç bağlanmaması önemli bir eksikliktir. 18 yaşından küçüklerin işlediği suç -objektif koşul bakımından- HAGB engeli olmamalı ve bu konuda CMK m. 231/5 veya ÇKK m. 23'te düzenleme yapılmalıdır.

3- Maddi zarar tazmini olarak anlaşılan CMK m. 231/6-c hükmünde, mağdurun iradesinin dikkate alınmaması mühim bir eksikliktir. Somut zararın tazmini yönüyle, mağdurun iradesi yasal koşula dahil edilmelidir. Sanık açısından ise, ileride beraat etme ihtimalinde başvurulacak özel bir tazmin düzenlemesi getirilmesi isabetli olacaktır.

4- Özel bir erteleme kurumu olan HAGB'nin içeriği hakkında sadece mahkeme tarafından yapılacak bilgilendirme yeterli değildir. $\mathrm{Bu}$ evrede müdafi yardımı şart koşulmalı, irade açıklaması da müdafiin katılımıyla gerçekleşmelidir. Ayrıca, HAGB'nin içeriğinde mahkeme tarafindan sabit görülen suç ve karşılığında kararlaştırılan bir mahkumiyetin varlığı yatmaktadır. $\mathrm{Bu}$ temelde sanığın HAGB'yi kabulü, suçun ikrarı anlamı taşımaktadır. Beraat edeceğini düşünen sanığın HAGB'yi zaten reddedeceği savunulabilirse de, hem mevcut yasal düzenlemede müdafi yardımının şart olmayışı, hem de sanığın HAGB'yi lehe kurum olarak algılaması, genel nitelikteki yorumları boşa çıkaracaktır. Böylece kabul beyanı, sanık hakkında devam eden veya aynı konuda bir başka yargılamada delil değeri taşıyacaktır. O halde, tıpk1 CMK m. 250/10'da olduğu gibi, CMK m. 231'e şu şekilde bir ekleme yapılmalı ve sanık iradesi hukuki güvenceye kavuşturulmalıdır: "Sanı̆̆ın, müdafii huzurunda hükmün açıklanmasının geri bırakılmasını kabul ettiğine ilişkin beyanı, takip eden veya aynı konu hakkındaki başka bir soruşturma ve kovuşturma işleminde delil olarak kullanılamaz".

5- Sanığın kabulüne ilişkin diğer tespit ve eleştirimiz ise, bizzat kabul şartının varlığına ilişkindir. HAGB'yi kabul eden sanığın, kabul ettiği kuruma itiraz etme hakkı olması, içerik itibarıyla çelişkili görünmektedir. Sanığın kabulü şartı yasadaki varlığını koruyacaksa, kabul şekline ilişkin önerimizin yanında, bu karara karşı öngörülen kanun yolunun da istinaf olması, sorununun aydınlatılmasına katkı sunacaktır. 
6- Denetim süresi ve denetimli serbestlik tedbiri için öngörülen süre üst sınırları, her iki kurumun amacı dikkate alındığında, birbirleriyle uyumsuz görünmektedir. $\mathrm{Bu}$ nedenle, ya denetim süresi daha kısa tutulmalı, ya da açıklanması ertelenen hükümde yer alan ceza miktarını aşmamak üzere, işlenen suçun niteliğine göre tedbirin uygulanma süresi daha uzun belirlenebilmelidir.

7- Sanığın devam eden muhakeme sürecinde beraat etmesi halinde, önceden kendisine yüklenen denetimli serbestlik tedbirinin, sanık hakkında aleyhe sonuç doğuracağı açıktır ve bu sonucun hukuken nasıl telafi edilebileceğinin yasada gösterilmemesi mühim bir eksikliktir. Ayrıca, denetimli serbestlik tedbirine ilişkin yükümlülüklere aykırı davranılması halinde mahkemenin TCK m. 50’ye istisnasız şekilde başvurabilmesine imkan tanınması, cezanın etkinliğini olumsuz etkileyeceğinden, doğru bir tercih olarak görünmemektedir.

8- Suçu sabit görülmesine rağmen hakkındaki hükmün uygulanması askıya alınan sanı̆̆ın, bu imkan karşısında belli yükümlülüklere katlanmasını beklemek doğaldır. Ancak askıda bekleyen hükmün açıklanmasını gerektiren bir durum ortaya çıktığında, belli yükümlülükleri yerine getiren sanık hakkında bu edimine karşılık cezadan mahsup imkanı tanınması da isabetli olacaktır.

9- Denetim süresi içinde kasıtlı bir suç işlenmesi halinde hükmün açıklanacağına ilişkin düzenleme (CMK m. 231/10-11), failin kusurluluk değerlendirmesini dikkate almadığından TCK'da benimsenen suç tanım ve yapısıyla uyumsuzdur. Öyle ki bu şartlarda; taksirli bir suç işlenmesi halinde HAGB kararı etkilenmezken, sanığın mesela TCK m. 28 şartlarında bir suç işlemesi, askıdaki hükmün açıklanmasını gerektirecektir. Bu endişenin giderilmesi için yasa metnindeki ifadenin "kasten işlediği bir suçtan mahkum olmadı ̆̆ $\imath$ " şeklinde değiştirilmesi gerekir.

10- Denetim süresi içinde ancak kasten işlenen suç, hükmün açıklanması sonucunu doğuracaktır. Oysa neticenin fail tarafından öngörüldüğü bilinçli taksir durumunda da, somut olayın şartları dikkate alınarak, HAGB'nin failden beklenen dikkat ve özene halel getirip getirmediği mahkemece tahlil edilmeli ve HAGB'nin varlığı ya da hükmün açıklanmasına karar verilmelidir. Bu amaçla tarafımızca, CMK m. 231/10 veya m. 231/11'in sonuna olmak üzere, "Sanığın, denetim süresi içinde bilinçli taksirle işlediği bir suçtan mahkum olması halinde mahkeme, fiilin işlenişi ve sanığın durumunu değerlendirerek hükmü açıklayabilir" şeklinde bir cümlenin eklenmesi önerilmektedir.

11- CMK m. 280/2'de, "yeniden hüküm kurar" ifadesiyle, "hüküm" 
kavramına açık bir atıf yapılmıştır. Hüküm çeşitleri CMK m. 223'te tanımlandığı halde, istinaf aşamasında HAGB kararı verilmektedir. Bu tutum, HAGB'nin mahkumiyet kararına dayanması yönüyle desteklenebilir. Ancak bu yorum ile HAGB için öngörülen kanun yolu tanımlanmasının kendi içinde uyumsuz olduğu söylenmelidir. Ayrıca, itiraz merciinin yetki sınırlarının, HAGB'nin doğurduğu hukuki neticeler ölçüsünde içtihatla genişletilmesi, ucu açı bir çabadır. Nitekim itirazın yerinde bulunması halinde dosyanın esas mahkemeye gönderilmesi, itiraz ve HAGB arasında bir uyum yakalama gayretinin işaretidir. Bunun yerine, kanun yolunun istinaf olarak benimsenmesi hem birçok hukuki sorunu açıklığa kavuşturup kurumlar arası uyumluluğa hem de usul ekonomisi ve adil yargılanma hakkına önemli derecede katk1 sağlayacaktır.

\section{KAYNAKÇA}

Adli Sicil ve İstatistik Genel Müdürlüğü, Adli İstatistikler 2019, <https:// adlisicil.adalet.gov.tr/Resimler/SayfaDokuman/1062020170359Hizmet eOzel-2019-bask\%C4\%B1-\%C4\%B0SA.pdf> Erişim Tarihi 31 Ağustos 2021.

Akbulut B/Aksan M, Ceza Muhakemesi Hukukunda Uzlaştırma, 2. Bask1, Seçkin Yayınevi 2019.

Akkaş A.H, Bir Güvenlik Tedbiri Türü Olarak Belli Hakları Kullanmaktan Yoksun Bırakılma (Hak Yoksunlukları), Adalet Yayınevi 2021.

Akyıldız A, "Hükmün Açıklanmasının Geri Bırakılması Kurumuna İlişkin Sorunlar”, 2020, 17(3), YÜHFD, s. 65-88.

Akyürek G, Yargılamanın Yenilenmesi, 3. Baskı, Seçkin Yayınevi 2018.

Aras B, "Hükmün Açıklanmasının Geri Bırakılması Kurumu ve Uygulamadaki Sorunlar", 2008, 3(22), THD, s. 71-88.

Artuç M, "Hükmün Açıklanmasının Geri Bırakılması", 2008, 3(21), THD, s. 107-126.

Artuç M/Hırslı T, Hüküm Kurma Esasları, 4. Baskı, Adalet Yayınevi 2011.

Artuk M.E/Gökcen A/Alşahin M.E./Çakır K, Ceza Hukuku Genel Hükümler, 12. Bask1, Adalet Yayınevi 2018. 
Balo Y.S, "HükmünAçıklanmasının Ertelenmesi Kurumu Üzerinden Ulaşı1mak İstenen Hedeflerin Türkiye Bakımından Gerçekleştirilebilirliği”, 2016, 11(30), CHD, s. 165-206.

Baştürk İ, Hükmün Açıklanmasının Ertelenmesi, Adalet Yayınevi 2014.

Beck'sche Online Kommentare, Strafgesetzbuch (48. Edition-1.2.2021) (BeckOKStGB/Yazar).

Birtek F, Ceza Muhakemesinde İstinaf, Adalet Yayınevi 2019.

Centel N/Zafer H, Ceza Muhakemesi Hukuku, 19. Bas1, Beta Yayınevi 2020.

Çığlı H, "Yargıtay Kararları Çerçevesinde, Hükmün Açıklanmasının Geri Bırakılmasında Daha Önceden Kasıtll Bir Suçtan Mahkum Olmama Şartına İlişkin Bir Değerlendirme”, 2014, 9(100), THD, s. 17-23.

Çınarlı S./Arslan Hızal S, "Hükmün Açıklanmasının Geri Bırakılmasının Memuriyete Giriş ve Memuriyetin Sona Ermesine Etkisi”, 2017, 12(134), THD, s. 14-30.

Demirbaş T, Ceza Hukuku Genel Hükümler, 15. Baskı, Seçkin Yayınevi 2020.

Dursun E, "Hükmün Açıklanmasının Geri Bırakılmasına İlişkin Teorik Bir İnceleme", 2014, 9(26), CHD, s. 145-170.

Dülger M.V, Ceza Hukuku Genel Hükümler, 1. Baskı, Hukuk Akademisi Yayınevi 2021.

Değirmenci O, Onarıcı Adalet Uygulaması Olarak Ceza Muhakemesinde Uzlaştırma, Seçkin Yayınevi 2020.

Değirmenci O, "Yargı Kararları Çerçevesinde HAGB Kararının Hukuki Denetimi ve İtirazın Kapsamı", Türk Ceza Muhakemesi Hukukunda Kanun Yolları, 2019, 1(2), Erciyes Üniversitesi Hukuk Fakültesi Sempozyum Dergisi, s. 71-106.

Epözdemir R, Hükmün Açıklanmasının Geri Bırakılması, 2. Baskı, Adalet Yayınevi 2017.

Ersoy U, Ceza Muhakemesi Hukukunda Aleyhe Değiştirme (reformatio in peius) Yasağı, Adalet Yayınevi 2018.

Fischer T, Strafgesetzbuch, 66. Bask1, C.H.Beck 2019.

Füglein F/Pascal L, "Geld habe ich keines, aber arbeiten kann ich- Die Verwarnung mit Strafvorbehalt", 2013, ZRP, s. 48-50. 
Gökcen A/Balcı M/Alşahin M.E/Çakır K, Ceza Muhakemesi Hukuku, 4. Bask1, Adalet Yayınevi 2020.

Güner U, “Türk Ceza Hukukunda Mahkumiyet Hükmünün Açıklanmasının Ertelenmesi", 2014, 9(25), CHD, s. 181-200.

Güneş S, Hükmün Açıklanmasının Geri Bırakılması, On İki Levha Yayınevi 2018.

Güngör D/Okuyucu-Ergün G, "Hükmün Açıklanmasının Geri Bırakılması", 2016, 65(4), AÜHFD, s. 1951-1965.

Güngör D/Toroslu H, "Müsadere ve Hükmün Açıklanmasının Geri Bırakılmas1 İlişkisi Üzerine Kısa Bir Değerlendirme”, 2016, 65(4), AÜHFD, s. 19671980.

Gürühan C, "Hükmün Açıklanmasının Geri Bırakılmasına İlişkin Güncel Sorunların Yargıtay Kararları Işığında Değerlendirilmesi”, 2014, 26(111), TBBD, s. 133-162.

İpek A. İ, Hükmün Açıklanmasının Geri Bırakılması, Adalet Yayınevi 2010.

İtişgen R, "Ceza Muhakemesi Hukukunda İstinaf”, 2014, 5(16), TAAD, s. 373-404.

Kale H, "Hükmün Açıklanmasının Geri Bırakılmasının Disiplin Cezalarına Etkisi”, 2011, 6(60), THD, s. 45-47.

Kapancı K. B, "Ceza Mahkemesi Kararlarının Hukuk Mahkemesi Kararlarına Etkisi (TBK m. 74)”, 2016, 7(1), İnÜHFD, s. 511-552.

Kaplan M, "Onarıcı Adalet ve Türk Ceza Hukukuna Yansımaları", 2015, 5(1), AkdHFD, s. 59-86.

Karakehya H, Ceza Muhakemesi Hukuku, 2. Bası, Savaş Yayınevi 2016.

Kartal A, "Hapis Cezasının Ertelenmesi ile Hükmün Açıklanmasının Geri Bırakılmasının Sonuçları Bakımından Karşılaştırılması", 2016, 11(114), THD, s. 67-74.

Kaya E, "İnsan Hakları Açısından Hükmün Açıklanmasının Geri Bırakılması”, 2013, 3, AnkBD, s. 411-436.

Kaymaz S, “Aleyhe Değiştirme Yasağı”, 2013, 19(2), MÜHF-HAD, (Prof. Dr. Nur Centel'e Armağan), s. 1397-1451.

Kılıç A.Ş, "Ceza Muhakemesinde İstinaf Kanun Yoluna Teorik Bir Bakış”, 
2019, 1(2), Erciyes Üniversitesi Hukuk Fakültesi Sempozyum Dergisi, s. $107-130$.

Koca M/Üzülmez İ, Türk Ceza Hukuku Genel Hükümler, 13. Baskı, Seçkin Yayınevi 2020.

Kropp C, "Ist die Verwarnung mit Strafvorbehalt noch zeitgemäß?", 2004, ZRP, s. 241.

Kumbasar E, Hükmün Açıklanmasının Geri Bırakılması, Seçkin Yayınevi 2012.

Kühne H, Strafprozessrecht, 8. Bask1, C.F.Müller 2010.

Meran N, "Hükmün Açıklanmasının Geri Bırakılması Konusunda Bazı Çözüm Önerileri”, 2008, 3(23), THD, s. 61-73.

Münchener Kommentar zum StGB, 4. Bask1, C.H.Beck Yayınevi 2020 (MüKoStGB/Yazar).

Olgun S, "Ceza Muhakemesi Kanununa Göre Hükmün Açılanmasının Geri Birakılmas1", 2008, 3(22), THD, s. 63-69.

Özbek V.Ö/Doğan K/Bacaksız P, Ceza Muhakemesi Hukuku, 12. Bask1, Seçkin Yayınevi 2019.

Özbek V.Ö/Başbüyük İ, "Hükmün Açıklanmasının Geriye Bırakılması Kararlarına İtirazın İncelenme Usulünün Mağdur/Suçtan Zarar Gören Bakımından Ortaya Çıkardığı Sorun Üzerine”, 2013, 8(21), CHD, s. 7-19.

Özbek V.Ö/Meraklı S, "Karar İncelemesi: Hükmün Açıklanmasının Geri Birakılmas1 Kararına İtiraz Üzerine Yapılacak Denetim”, 2013, 19(2), MÜHF-HAD, (Prof. Dr. Nur Centel'e Armağan), s. 221-236.

Özen M, Öğreti ve Uygulama Işığında Ceza Muhakemesi Hukuku, 2. Bask1, Adalet Yayınevi 2018.

Özgenç İ, Türk Ceza Hukuku Genel Hükümler, 14. Bası, Seçkin Yayınevi 2018.

Öztürk B (Editör), Nazari ve Uygulamalı Ceza Muhakemesi Hukuku, 13. Bask1, Seçkin Yayınevi 2019.

Parlar A, Hükmün Açıklanmasının Geri Bırakılması ve Erteleme, 2. Bası, Bilge Yayınevi 2015. 
Putzke H/Scheinfeld J, Strafprozessrecht, 3. Baskı, C.H.Beck Yayınevi 2011.

Sarıgül A.T, "Hükmün Açıklanmasının Geri Bırakılması Kararlarının Denetiminde Kanun Yolu Sorunu”, 2016, 29(125), TBBD, s. 59-84.

Sarıgül A.T, "Türk ve Alman Hukuku'nda Hükmün Açıklanmasının Geri Birakılması", 2015, 118, TBBD, s. 125-162.

Sencer S/Kurşun A. S, "Hükmün Açıklanmasının Geri Bırakılmasının Hukuk Davalarına Etkisi”, 2017, 12(129), THD, s. 33-49.

Soyaslan D, Ceza Muhakemesi Hukuku, 7. Bask1, Yetkin Yayınevi 2018.

Strafgesetzbuch Kommentar Schönke/Schröder, 30. Baskı, C.H.Beck Yayınevi 2019 (S/S-Yazar).

Şahin C, "Hükmün Açıklanmasının Geri Bırakılması Kararına İtirazda İncelemenin Kapsamı", 2013, 19(2), MÜHF-HAD, (Prof. Dr. Nur Centel'e Armağan), s. 283-294.

Şahin C/Göktürk N, Ceza Muhakemesi Hukuku -II-, 7. Bası, Seçkin Yayınevi 2018.

Şen E/Maviş M, Hükmün Açıklanmasının Geri Bırakılması (HAGB), Seçkin Yayınevi 2014.

Taner F.G, Ceza Muhakemesi Hukukunda Adil Yargılanma Hakkı Bağlamında Çelişme ve Silahların Eşitliği, Seçkin Yayınevi 2019.

Taner F.G, "Hükmün Açıklanmasının Ertelenmesinin (Geri Bırakılmasının) Hukuki Niteliği ve Ertelemeyi Kabul Edip Etmediğinin Sanığa Duruşma Devresinin Sona Ermesinden Önce Sorulmasının Hukuka Aykırılığı Üzerine", 2011, 4, AnkBD, s. 287-298.

Taşdemir K, Hükmün Açıklanmasının Geri Bırakılması, (Yazarın kendi yayın1) 2016.

Temur T, "Hükmün Açıklanmasının Geri Bırakılması", 2014, 88(5), THD, s. 140-159.

Toroslu N/Feyzioğlu M, Ceza Muhakemesi Hukuku, 20. Bask1, Savaş Yayınevi 2020.

Tulay M.E/Doğan Y, “Türk Ceza Muhakemesi Hukukunda Basit Yargılama Usulü”, 2020, 10(2), AkdHFD, s. 349-376.

Tulay M.E, "Kanunilik İlkesi Işığında Ceza Kanunlarının Zaman Bakımından 
Uygulanması ve Delil Elde Etme Yöntemlerinde Zaman Bakımından Uygulanma Sorunu", 2016, 22(3), MÜHF-HAD, Prof. Dr. Cevdet Yavuz'a Armağan, s. 2715-2736.

Turhan F, Ceza Muhakemesi Hukuku, 1. Bask1, Asil Yayınevi 2006.

Turhan F, "Yeni Türk Ceza Kanunu'na Göre Cezaların Ertelenmesi ve Uygulamada Ortaya Çıkan Bazı Sorunlar", 2006, X(3-4), EÜHFD, s. 27-54.

Uludaş İ, "Hükmün Açıklanmasının Geri Bırakılması Kurumunun ve 6545 Sayılı Yasa ile Getirilen Değişikliğin Değerlendirilmesi”, 2014, 6(56), FHD, s. 15-19.

Ünal E, "Uzlaştırma ve Hükmün Açıklanmasının Geri Bırakılması Kurumlarının Masumiyet Karinesi Bağlamında Değerlendirilmesi”, 2018, 17(1), İKÜHFD, s. 195-216.

Ünver Y/ Hakeri H, Ceza Muhakemesi Hukuku, 17. Bask1, Adalet Yayınevi 2020.

Yalçın C, Hükmün Açıklanmasının Geri Bırakılması, Seçkin Yayınevi 2021.

Yavuz H.A, Ceza Muhakemesinde Kovuşturmaya Alternatif Yöntemler, Adalet Yayınevi 2019.

Yenisey F/Nuhoğlu A, Ceza Muhakemesi Hukuku, 8. Baskı, Seçkin Yayınevi 2020.

Yenisey, F/Plagemann G, Alman Ceza Kanunu Strafgesetzbuch (StGB), 2. Bask1, Beta Yayınevi 2015.

Yıldırım A, "Mayınlı Bir Alan: Hükmün Açıklanmasının Geri Bırakılması Kararının Denetimi”, 2018, 11, Uyuşmazlık Mahkemesi Dergisi, s. 435480.

Yurtcan E, Ceza Yargılaması Hukuku, 16. Bası, Seçkin Yayınevi 2019.

Zafer H, Ceza Hukuku Genel Hükümler, 7. Bası, Beta Yayınevi 2019. 
